\title{
Review \\ The Role of Long Non-Coding RNA and microRNA Networks in Hepatocellular Carcinoma and Its Tumor Microenvironment
}

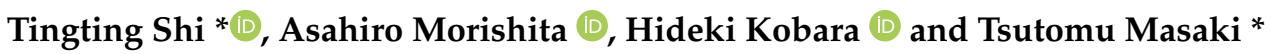 \\ Department of Gastroenterology and Neurology, Faculty of Medicine, Kagawa University, 1750-1 Ikenobe, \\ Miki 761-0793, Japan; asahiro@med.kagawa-u.ac.jp (A.M.); kobara@med.kagawa-u.ac.jp (H.K.) \\ * Correspondence: shitingtingc@med.kagawa-u.ac.jp (T.S.); tmasaki@med.kagawa-u.ac.jp (T.M.); \\ Tel.: +81-87-891-2156 (T.M.); Fax: +81-87-891-2158 (T.M.)
}

Citation: Shi, T.; Morishita, A.; Kobara, H.; Masaki, T. The Role of Long Non-Coding RNA and microRNA Networks in Hepatocellular Carcinoma and Its Tumor Microenvironment. Int. J. Mol. Sci. 2021, 22, 10630. https://doi.org/ 10.3390/ijms221910630

Academic Editor: Young-Ho Ahn

Received: 6 September 2021

Accepted: 27 September 2021

Published: 30 September 2021

Publisher's Note: MDPI stays neutral with regard to jurisdictional claims in published maps and institutional affiliations.

Copyright: (c) 2021 by the authors. Licensee MDPI, Basel, Switzerland. This article is an open access article distributed under the terms and conditions of the Creative Commons Attribution (CC BY) license (https:/ / creativecommons.org/licenses/by/ $4.0 /)$.

\begin{abstract}
Hepatocellular carcinoma (HCC) is a common liver malignancy with high morbidity and poor prognosis. Long non-coding RNAs (lncRNAs) are involved in crucial biological processes of tumorigenesis and progression, and play four major regulatory roles, namely signal, decoy, guide, and scaffold, to regulate gene expression. Through these processes, lncRNAs can target microRNAs (miRNAs) to form lncRNA and miRNA networks, which regulate cancer cell proliferation, metastasis, drug resistance, and the tumor microenvironment. Here, we summarize the multifaceted functions of lncRNA and miRNA networks in the pathogenesis of HCC, the potential use of diagnostic or prognostic biomarkers, and novel therapeutic targets in HCC. This review also highlights the regulatory effects of lncRNA and miRNA networks in the tumor microenvironment of HCC.
\end{abstract}

Keywords: hepatocellular carcinoma; microRNA; long non-coding RNA; tumor microenvironment; biological function

\section{Introduction}

Hepatocellular carcinoma (HCC) is a common liver malignancy with high morbidity and poor prognosis. Recent global cancer statistics indicate that primary liver cancer is the sixth most commonly diagnosed cancer and the third leading cause of cancer death with approximately 906,000 new cases and 830,000 deaths (8.3\%) occurring in 2020 [1]. HCC constitutes $75-85 \%$ of primary liver cancers. Risk factors, including hepatitis virus (hepatitis $\mathrm{B}$ virus, $\mathrm{HBV}$ or hepatitis $\mathrm{C}$ virus, $\mathrm{HCV}$ ) infection, alcohol abuse, metabolic liver disease, type 2 diabetes, and exposure to dietary toxins (aflatoxins and aristolochic acid), vary from region to region [1,2]. These risk factors provoke an inflammatory response and liver injury, which promotes liver fibrosis, epigenetic changes during hepatocyte renewal, and microenvironment changes $[3,4]$. These changes enhance liver damage, and chronic positive feedback accelerates tumorigenesis $[3,4]$. The strategy of HCC treatment depends on the stage of HCC: For early stage, ablation, resection, and liver transplantation could be curative therapy; transarterial chemoembolization (TACE), transarterial embolization (TAE), transarterial radioembolization (TARE), and systemic treatment (sorafenib, lenvatinib [5] as first-line therapy) could be used for intermediate-stage HCC; for advanced-stage, systemic treatment with multi-kinase inhibitors or immune checkpoint inhibitors could prolong the overall survival (OS) rates [2]. However, the current 5-year cause-specific survival rate remains low [6]. Thus, early diagnosis and intervention play a key role in improving HCC survival.

MicroRNAs (miRNAs) and long non-coding RNAs (lncRNAs) are non-coding RNAs. miRNAs are approximately 17-25 nucleotides long and their major biological function is regulating target gene expression by binding to the $3^{\prime}$-UTR of target mRNAs, which is associated with cell proliferation, cell death, and signaling pathway regulation [7]. Furthermore, miRNAs with similar sequences are organized in clusters, leading to combinatorial diversity and synergy in biological functions [8]. In humans, approximately $30 \%$ of genes are 
regulated by miRNAs, and miRNA regulation is closely associated with various diseases, particularly cancers [9].

lncRNAs, which are over 200 nucleotides in length, do not translate into proteins; however, their secondary structures or three-dimensional structures enable them to have protein-like functions $[10,11]$. IncRNAs are involved in diverse biological processes via binding to DNA, RNA, and proteins [12] and play four main regulatory roles, including signal, decoy, guide, and scaffold, to regulate gene expression [13]. The functions of lncRNAs include the modification of chromatin through lncRNA-protein or lncRNA-DNA interactions; the activation or repression of transcription by interaction with transcriptional coactivators or acting as a decoy to keep transcriptional activators away; translation control of proteins; the stabilization of mRNA; the degradation of mRNA; playing the role of competing endogenous RNA (ceRNA) by interacting with miRNAs; miRNA production; and the regulation of the phosphorylation, methylation, and ubiquitination of mRNA and protein modifications [14]. In addition, the intercellular transfer of non-coding RNAs through extracellular vesicles (EVs), such as miRNAs, can modulate cellular function even in the microenvironment [15].

Recently, an increasing number of studies have focused on the emerging roles of lncRNAs and miRNAs in HCC and the tumor microenvironment [16-18]. In this review, the lncRNA and miRNA networks in HCC and the tumor microenvironment have been discussed. We summarize the multifaceted functions of lncRNA and miRNA networks underlying the pathogenesis of HCC, the potential use of diagnostic or prognostic biomarkers, and novel therapeutic targets in HCC.

\section{Biological Functional Relationship between lncRNAs and miRNAs}

The biological functional relationship between lncRNA and miRNA may be briefly summarized as miRNA sponges (ceRNA), competitive binding to miRNA target genes, miRNA production from IncRNAs, and lncRNA degradation. In detail, IncRNAs act as ceRNAs by binding target miRNAs to prevent the binding of miRNAs to their target genes, upregulating target gene expression, which functions as the lncRNA-miRNA-mRNA axis. To date, most studies have focused on this interaction axis. In addition, lncRNAs can also bind to sites on the target genes of miRNAs to regulate their corresponding miRNA activity $[14,19]$. IncRNAs, which contain miRNA sequences, can produce miRNAs by Dicer and/or Drosha cleavage and regulate different points of miRNA biogenesis, affecting microprocessor activity to finish the primary transcript independent of polyadenylation [20]. miRNAs can bind target lncRNAs to regulate the stability and half-life of lncRNAs [20,21]. These complex interactions between lncRNAs and miRNAs constitute the lncRNA and miRNA networks, mainly through sequence complementarity (Figure 1). 


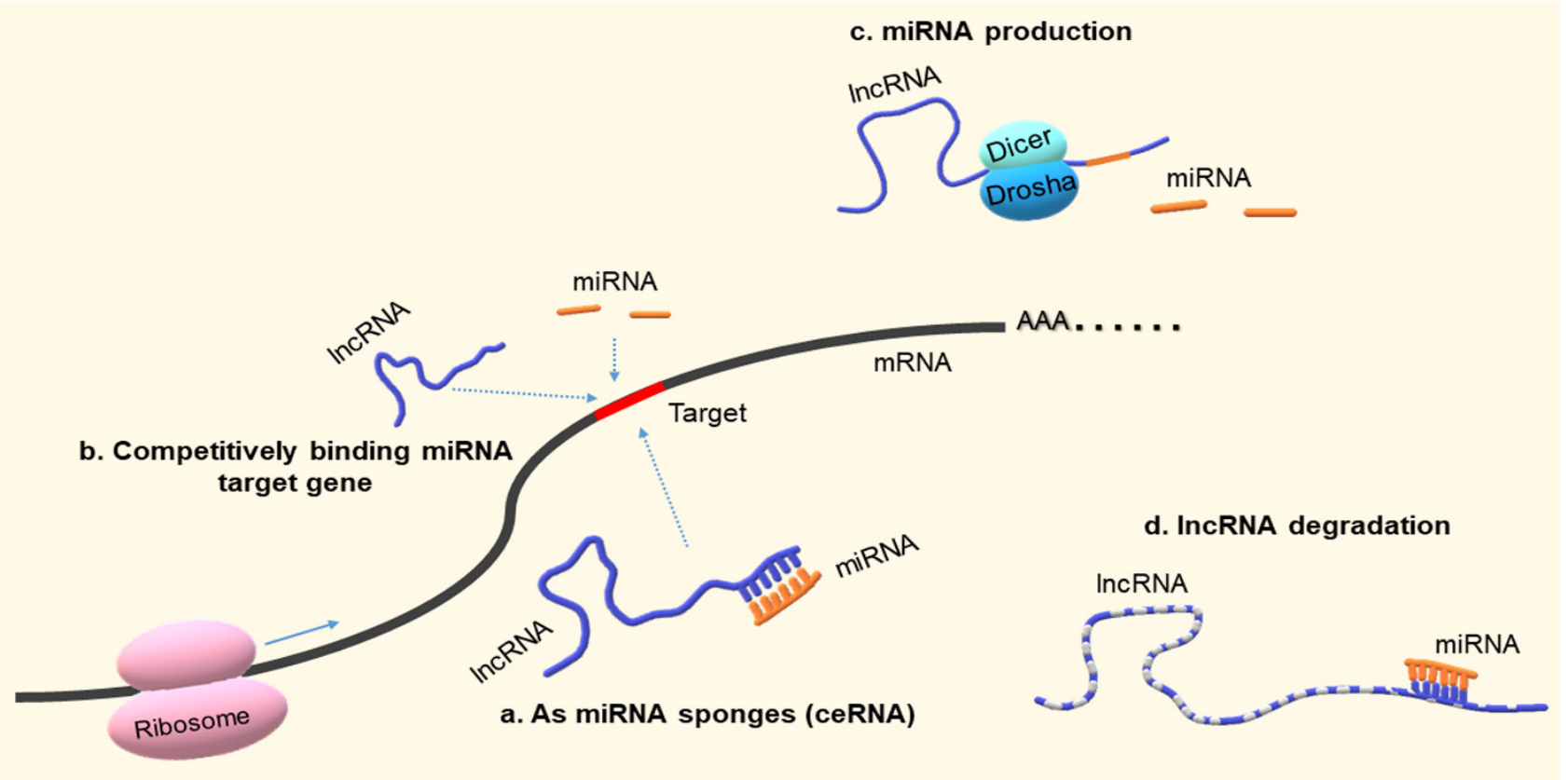

Figure 1. The biological functional relationship between long non-coding RNA and microRNA. lncRNA, long non-coding RNA; miRNA, microRNA; ceRNA, competing endogenous RNA.

\section{Role of lncRNA and miRNA Networks in HCC}

The interaction and regulation of lncRNAs and miRNAs can have a direct effect on the corresponding target genes and regulate the translation of proteins, which play an important role in tumorigenesis and the progression of several types of cancers, including HCC, mainly through the lncRNA-miRNA-mRNA axis. During the development and progression of cancers, some miRNAs, which act as oncogenic miRNAs, are upregulated, while others, which act as tumor suppressors, are downregulated [22]. Thus, in the lncRNA and miRNA networks, dominating lncRNAs that bind to oncogenic miRNAs act as suppressors; on the contrary, those that bind to inhibitor miRNAs play the role of promoters (Table 1$)$.

\subsection{Promoting Effect of $\operatorname{lncRNA}$ and miRNA Networks in HCC}

Studies of the IncRNA-miRNA-mRNA axis are majorly represented in the lncRNA and miRNA networks. The lncRNA myocardial infarction-associated transcript (MIAT) is overexpressed in HCC tissues and cells, promotes HCC cell proliferation and invasion by directly sponging miR-214, and upregulates the expression of the enhancer of zeste homolog 2 (EZH2) and $\beta$-catenin [23]. EZH2 acts as a key regulator of cell-cycle progression, promotes DNA damage repair, and accelerates cell proliferation that together contribute to carcinogenesis and cancer progression [68]. Additionally, EZH2 is overexpressed in HCC and is associated with a poor prognosis [69]. $\beta$-catenin is a key component of Wnt signaling, and its expression can be upregulated in cancer by stabilizing mutations, which stimulate WNT / $\beta$-catenin signaling. Dysregulation of the WNT/ $\beta$-catenin pathway is related to HCC, while up to $66 \%$ of HCC cases have aberrant WNT/ $\beta$-catenin signaling [70]. MIAT also acts as a ceRNA of miR-22-3p to upregulate the expression of sirt1 in HCC cells. Additionally, decreased MIAT activates the p53/p21 and p16/pRb pathways, which suppresses HCC cell proliferation [24]. The lncRNA HOXD cluster antisense RNA 1 (HOXD-AS1) is upregulated in HCC tissues and is positively associated with poor prognosis and node metastasis in HCC patients. HOXD-AS1 competitively sponges miR-130a-3p, which prevents Sry-related HMG box-4 (SOX4) degradation and activates EZH2 and matrix metalloproteinase-2 (MMP-2) protein expression to promote HCC metastasis [26]. HOXD-AS1 also upregulates the levels of Rho GTPase activating 
protein 11A (ARHGAP11A) by targeting miR-19a, which induces metastasis and reduces apoptotic effects [27]. Moreover, the silencing of HOXD-AS1 inhibits HCC cell proliferation, cell cycle progression, and invasion via the MEK/ERK pathway [71].

Table 1. Recent studies on the role of lncRNA and miRNA networks in hepatocellular carcinoma.

\begin{tabular}{|c|c|c|c|c|}
\hline LncRNA & MiRNA & $\begin{array}{l}\text { Target Gene of } \\
\text { miRNA }\end{array}$ & Mechanism & References \\
\hline \multicolumn{5}{|l|}{ Promotor } \\
\hline MIAT & miR-214; miR-22-3p & $\begin{array}{c}\text { EZH2, } \beta \text {-catenin; } \\
\text { SIRT1 }\end{array}$ & Proliferation, invasion & {$[23,24]$} \\
\hline MCM3AP-AS1 & miR-194-5p & FOXA1 & \multirow{2}{*}{$\begin{array}{c}\text { Proliferation, cell cycle and } \\
\text { apoptosis } \\
\text { metastasis }\end{array}$} & {$[25]$} \\
\hline HOXD-AS1 & $\begin{array}{l}\text { miR-130a-3p; miR19a } \\
\text { miR-6825-5p, }\end{array}$ & SOX4; ARHGAP11A & & {$[26,27]$} \\
\hline HULC & $\begin{array}{l}\text { miR-6845-5p and } \\
\text { miR-6886-3p }\end{array}$ & USP22 & Autophagy & [28] \\
\hline CDKN2BAS & miR-153-5p & ARHGAP18 & \multirow{3}{*}{$\begin{array}{l}\text { Proliferation, metastasis } \\
\text { Proliferation and migration } \\
\text { Invasion, metastasis }\end{array}$} & [29] \\
\hline FAL1 & miR-1236 & AFP, ZEB1 & & [30] \\
\hline ATB & miR-200 family & ZEB1, ZEB2 & & [31] \\
\hline LINC00662 & $\begin{array}{c}\text { miR-15a, miR-16, and } \\
\text { miR-107 }\end{array}$ & WNT3A & Proliferation, cell cycle, invasion & {$[32]$} \\
\hline $\begin{array}{l}\text { FLJ33360 } \\
\text { LINC00958 }\end{array}$ & $\begin{array}{l}\text { miR-140 } \\
\text { miR-3619-5p }\end{array}$ & $\begin{array}{l}\text { MMP9 } \\
\text { HDGF }\end{array}$ & \multirow{2}{*}{$\begin{array}{l}\text { Invasion, metastasis } \\
\text { Lipogenesis and progression } \\
\text { Epithelial-mesenchymal } \\
\text { transition (EMT) }\end{array}$} & $\begin{array}{l}{[33]} \\
{[34]}\end{array}$ \\
\hline SNHG3 & miR-128 & CD151 & & [35] \\
\hline H19 & miR-193b & MAPK1 & \multirow[t]{3}{*}{ Invasion, migration } & [36] \\
\hline MUF & miR-34a & Snail1 & & [37] \\
\hline NEAT1 & miR-124-3p & ATGL & & {$[38]$} \\
\hline DANCR & $\begin{array}{l}\text { miR-27a-3p; miR-214, } \\
\text { miR-320a and miR-199a }\end{array}$ & LIMK1; CTNNB1 & Proliferation, EMT & {$[39,40]$} \\
\hline CRNDE & miR-539-5p & POU2F1 & $\begin{array}{c}\text { Proliferation, migration, and } \\
\text { invasion }\end{array}$ & [41] \\
\hline AGAP2-AS1 & $\operatorname{miR}-16-5 p$ & ANXA11 & \multirow{3}{*}{$\begin{array}{l}\text { Metastasis and EMT } \\
\text { Proliferation, metastasis } \\
\text { Invasion and metastasis }\end{array}$} & [42] \\
\hline CDKN2B-AS1 & let-7c-5p & NAP1L1 & & [43] \\
\hline BACE1-AS & miR-377-3p & CELF1 & & {$[44]$} \\
\hline SNHG11 & miR-184 & AGO2 & $\begin{array}{l}\text { Proliferation, migration, } \\
\text { apoptosis, and autophagy }\end{array}$ & {$[45]$} \\
\hline LINC01224 & miR-330-5p & CHEK1 & \multirow{3}{*}{$\begin{array}{l}\text { Proliferation and migration } \\
\text { Proliferation and apoptosis } \\
\text { Proliferation, invasion, } \\
\text { metastasis, and angiogenesis }\end{array}$} & [46] \\
\hline PICSAR & miR-588 & EIF6 & & {$[47]$} \\
\hline MYLK-AS1 & $\operatorname{miR}-424-5 p$ & E2F7 & & {$[48]$} \\
\hline ST8SIA6-AS1 & miR-129-5p & DCAF4L2 & $\begin{array}{l}\text { Proliferation, migration, and } \\
\text { invasion }\end{array}$ & [49] \\
\hline SNHG16 & miR-605-3p & TRAF6 & \multirow{2}{*}{$\begin{array}{c}\text { Metastasis and EMT } \\
\text { Proliferation, migration, and } \\
\text { invasion }\end{array}$} & [50] \\
\hline OSER1-AS1 & $\operatorname{miR}-372-3 p$ & Rab23 & & [51] \\
\hline LINC00460 & miR-342-3p & AGR2 & \multirow{2}{*}{$\begin{array}{l}\text { Proliferation, metastasis } \\
\text { Proliferation, migration, invasion }\end{array}$} & [52] \\
\hline LINC00668 & $\operatorname{miR}-532-5 p$ & YY1 & & {$[53]$} \\
\hline $\begin{array}{l}\text { MALAT1 } \\
\text { Linc00152 }\end{array}$ & $\begin{array}{l}\operatorname{miR}-125 a-3 p \\
\operatorname{miR}-193 a / b-3 p\end{array}$ & $\begin{array}{l}\text { FOXM1 } \\
\text { CCND1 }\end{array}$ & \multirow{2}{*}{$\begin{array}{c}\text { Proliferation and metastasis } \\
\text { Proliferation }\end{array}$} & {$[54]$} \\
\hline Suppressor & & & & \\
\hline CASC2 & miR-367 & FBXW7 & \multirow{2}{*}{$\begin{array}{c}\text { EMT } \\
\begin{array}{c}\text { Proliferation, migration, and } \\
\text { invasion }\end{array}\end{array}$} & [56] \\
\hline EPB41L4A-AS2 & miR-301a-5p & FOXL1 & & {$[57]$} \\
\hline TCL6 & miR-106a-5p & PTEN & \multirow{2}{*}{$\begin{array}{c}\text { Proliferation } \\
\text { Proliferation, migration, and } \\
\text { invasion }\end{array}$} & [58] \\
\hline MEG3 & miR-544b & BTG2 & & [59] \\
\hline MAGI2-AS3 & miR-374b-5p & SMG1 & \multirow{3}{*}{$\begin{array}{c}\text { Proliferation and migration } \\
\text { Proliferation and apoptosis } \\
\text { Proliferation, migration, and } \\
\text { invasion }\end{array}$} & [60] \\
\hline LINC01018 & miR-182-5p & FOXO1 & & {$[61]$} \\
\hline DGCR5 & miR-346 & KLF14 & & {$[62]$} \\
\hline $\begin{array}{l}\text { MIR31HG } \\
\text { LINC01488 }\end{array}$ & $\begin{array}{c}\text { miR-575 } \\
\text { miR-124-3p/miR-138-5p }\end{array}$ & $\begin{array}{l}\text { ST7L } \\
\text { vimentin }\end{array}$ & \multirow{3}{*}{$\begin{array}{c}\text { Proliferation and metastasis } \\
\text { Metastasis and tumorigenesis } \\
\text { Proliferation, migration, and } \\
\text { invasion } \\
\text { EMT }\end{array}$} & {$[63]$} \\
\hline LINC00657 & miR-106a-5p & PTEN & & {$[65]$} \\
\hline TUSC7 & miR-10a & EphA4 & & [66] \\
\hline MIR22HG & $\operatorname{miR}-10 a-5 p$ & NCOR2 & $\begin{array}{l}\text { Proliferation, migration, and } \\
\text { invasion }\end{array}$ & {$[67]$} \\
\hline
\end{tabular}


A clinical study including $129 \mathrm{HCC}$ patients showed that the levels of serum lncRNA were highly upregulated in liver cancer (HULC); metastasis-associated lung adenocarcinoma transcript 1 (MALAT1), Linc00152, pituitary tumor-transforming 3 pseudogene (PTTG3P), SPRY4 intronic transcript 1 (SPRY4-IT1), ubiquitin-conjugating enzyme E2C pseudogene 3 (UBE2CP3), and urothelial carcinoma-associated 1 (UCA1) were significantly higher in HCC patients than in benign liver disease patients and healthy controls [72]. LncRNA dysregulation is also associated with carcinogenesis and could be used to predict HCC diagnosis and prognosis. The binding of lncRNA HULC to miR-6825-5p, miR-6845-5p, and miR-6886-3p upregulates ubiquitin-specific peptidase 22 (USP22) expression to stabilize Sirt1, which induces HCC cell autophagy. In addition, chemotherapeutic agents, such as 5-fluorouracil and pirarubicin (THP), induce HULC expression and protective autophagy in HCC cells [28]. Furthermore, HULC could enhance the stability of HBV covalently closed circular DNA (cccDNA) and activate HBV replication in HBV-positive HCC cells [73]. HULC also enhanced the Epithelial-mesenchymal transition (EMT) by acting as a ceRNA and binding to miR-200a-3p and increasing the expression of zinc finger E-box binding homeobox 1 (ZEB1), promoting tumorigenesis and metastasis [74]. MALAT1 sponges miR-125a-3p to upregulate forkhead box M1 (FOXM1) expression, which promotes HCC cell proliferation [54]. Moreover, MALAT1 facilitates HCC development by regulating glucose metabolism, enhancing glycolysis, and inhibiting gluconeogenesis [75]. The binding of lncRNA UCA1 to miR-216b upregulates the expression of fibroblast growth factor receptor 1 (FGFR1) to activate the ERK signaling pathway, which in turn promotes HCC progression [76].

\subsection{Inhibitory Effect of IncRNA and miRNA Networks in HCC}

The downregulation of IncRNA cancer susceptibility candidate 2 (CASC2) in HCC tissues and HCC cells and binding of CASC2 to miR-367 to upregulate F-box/WD repeatcontaining protein 7 (FBXW7) expression inhibits EMT in HCC [56]. Moreover, upregulation of CASC2 could improve cisplatin sensitivity by sponging miR-222 directly [77]. lncRNA MAGI2 antisense RNA 3 (MAGI2-AS3) has been found to be downregulated in HCC tissues and is negatively associated with lymph node metastasis, TNM stage, and overall survival. Upregulated MAGI2-AS3 directly binds to miR-374b-5p and positively regulates the expression of the suppressor with morphogenetic effects on genitalia family member 1 (SMG1) in HCC, which inhibits HCC cell proliferation and migration [60]. The lncRNA DiGeorge syndrome critical region gene 5 (DGCR5) was downregulated in HCC tissues and serum, which correlated closely with poor cancer-specific survival, with an overall 5-year rate of $10.3 \%$ in the low expression group and $36.6 \%$ in the high expression group, respectively [78]. Additionally, DGCR5 was found to act as a sponge of miR-346 to modulate the expression of Krüppel-like factor 14 (KLF14) and inhibit the development of HCC [62].

The lncRNA MIR22HG is associated with the initiation and progression of many human cancers. MIR22HG was reported to decrease in HCC tissues and predict the poor prognosis of HCC patients, as it functions as a tumor suppressor and inhibits cell proliferation and invasion by sponging miRNA-10a-5p to upregulate nuclear receptor co-repressor 2 (NCOR2) expression [67]. miR10a-5p is reported to promote HCC cell growth, migration, and invasion [67]. NCOR2 can disrupt the binding of $\beta$-catenin to the transducin-beta-like protein 1 (TBL1)/transducing-beta-like $1 \mathrm{X}$-linked receptor 1 (TBLR1) complex to inactivate the Wnt/ $\beta$-catenin pathway, thereby suppressing EMT [79]. Moreover, MIR22HG suppresses the proliferation and metastasis of cancer cells also through MIR22HG-derived miR-22-3p targeting high mobility group box 1 (HMGB1) and binding to human gene antigen $\mathrm{R}(H u R)$ [80]. HMGB, a damage-associated molecule, is a key tumor promoter in HCC. HuR can stabilize oncogenic mRNAs, such as CTNNB1, CCNB1, HIF1A, BCL2, and COX2, while MIR22HG preferentially binds to HuR and decreases the expression of these oncogenes, thereby destabilizing many oncogenes [80]. A recent study demonstrated that irradiation downregulates histone deacetylase (HDAC)-2 
expression and upregulates the expression of MIR22HG, which promotes the production of miR-22-5p. Overexpression of MIR22HG and miR-22-5p increases the sensitivity of HCC to radiotherapy [81].

\subsection{LncRNAs and microRNAs May Act as New Biomarkers in HCC Diagnosis and Prognosis}

Patients with HCC risk factors, such as HBV/HCV infection and cirrhosis, who were enrolled in a surveillance program showed a reduced HCC-related mortality rate and an increased early-stage diagnosis rate compared with unenrolled patients, although the survival benefit in patients with cirrhosis remains controversial [82]. The best-studied and most-used biomarker yet remains alpha fetoprotein (AFP), although it has been demonstrated to have poor sensitivity for HCC when used alone. A retrospective case-control study revealed that the sensitivity was only approximately $60 \%$ and the specificity was $80 \%$, even considering the most efficient cutoff $(10-20 \mathrm{ng} / \mathrm{mL})$ [83]. To increase detection sensitivity, it is important to minimize false-positive results of AFP. However, a metaanalysis study indicated that AFP with ultrasound detected early-stage HCC with $63 \%$ sensitivity ( $95 \% \mathrm{CI}, 48-75 \%)$, while that without ultrasound detected early-stage HCC with $45 \%$ sensitivity (95\% CI, 30-62\%) [84]. Moreover, a randomized controlled surveillance trial including $18,816 \mathrm{HBV}$ patients who underwent an AFP test and an ultrasonography examination every six months indicated that the mortality rate was significantly lower in the screened group $(83.2 / 100,000)$ than in controls $(131.5 / 100,000)$ [85]. From an economic point of view, AFP testing with ultrasonography examination is a good option for HCC surveillance but it currently remains insufficient as a biomarker. Serum biomarkers are an attractive choice for the surveillance, early diagnosis, and prognosis of HCC because they allow non-invasive, objective, and reproducible evaluation [83]. Therefore, there is increasing interest in serum biomarkers that may improve sensitivity for the early detection of HCC (Tables 2 and 3).

Table 2. Recent studies on the expression levels of potential lncRNA-based biomarkers in hepatocellular carcinoma.

\begin{tabular}{|c|c|c|c|c|c|}
\hline LncRNA & Expression & $\begin{array}{c}\text { Detectable } \\
\text { Location }\end{array}$ & Background & $\begin{array}{l}\text { Biomarker } \\
\text { Category }\end{array}$ & References \\
\hline ZFAS1 & upregulated & plasma & - & diagnosis & [86] \\
\hline LINC00853 & upregulated & $\begin{array}{l}\text { serum extracellular } \\
\text { vesicle }\end{array}$ & - & diagnosis & [87] \\
\hline TSPAN12 & upregulated & tissues & HCC with MVI & diagnosis/prognosis & [88] \\
\hline SEMA6A-AS1 & downregulated & tissues & HBV-HCC & prognosis & [89] \\
\hline SOX2OT & upregulated & tissues & - & prognosis & [90] \\
\hline UCA1 & upregulated & serum, tissues & - & diagnosis/prognosis & [91] \\
\hline WRAP53 & upregulated & serum, tissues & - & diagnosis/prognosis & [91] \\
\hline DGCR5 & downregulated & serum, tissues & - & diagnosis/prognosis & [78] \\
\hline PANDAR & upregulated & tissues & - & prognosis & [92] \\
\hline HOTTIP & upregulated & tissues & - & prognosis & [93] \\
\hline LINC00161 & upregulated & serum, exosome & - & diagnosis & [94] \\
\hline LOC101926913 & upregulated & tissues & - & prognosis & [95] \\
\hline LINC00152 & upregulated & serum & - & diagnosis & [72] \\
\hline NONHSAT053785 & upregulated & serum & - & diagnosis & [96] \\
\hline
\end{tabular}

Abbreviations: LncRNA, long non-coding RNA; MVI, microvascular invasion. 
Table 3. Recent studies on the expression levels of potential circulating miRNA biomarkers in hepatocellular carcinoma.

\begin{tabular}{cccccc}
\hline MiRNA & Expression & $\begin{array}{c}\text { Detectable } \\
\text { Location }\end{array}$ & Background & $\begin{array}{c}\text { Biomarker } \\
\text { Category }\end{array}$ & References \\
miR-21 & upregulated & serum & - & diagnosis & {$[97]$} \\
miR-122 & upregulated & serum & - & diagnosis/prognosis & {$[98,99]$} \\
miR-665 & upregulated & serum & - & prognosis & {$[100]$} \\
miR-148a & downregulated & plasma & - & diagnosis & {$[101]$} \\
miR-10b-5p & upregulated & serum exosome & - & prognosis & {$[102]$} \\
miR-215-5p & upregulated & serum exosome & - & diagnosis & {$[102]$} \\
miR-126 & upregulated & plasma & HBV-HCC & diagnosis/prognosis & {$[103]$} \\
miR-424 & downregulated & serum & - & dis] \\
\hline
\end{tabular}

Abbreviations: miR, MicroRNA.

Recent studies suggest that lncRNA may act as a new biomarker for HCC diagnosis and prognosis (Table 2). The levels of plasma lncRNA zinc finger antisense 1 (ZFAS1) were significantly higher in HCC patients than those in healthy controls (AUC $=0.801$, $95 \%$ CI: 0.724-0.875), with a sensitivity and specificity of $55.7 \%$ and $90.0 \%$, respectively. Moreover, a combination of AFP and ZFAS1 increased the diagnostic efficiency (AUC $=0.891$, 95\% CI: 0.829-0.953) [86]. Serum extracellular vesicle-derived lncRNA LINC00853 was increased in HCC patients and showed obvious discriminatory ability in the diagnosis (AUC $=0.934,95 \%$ CI: $0.887-0.966$ ) with a sensitivity of $93.75 \%$ and specificity of $89.77 \%$. At the same time, serum EV-derived LINC00853 showed 97\% positivity in AFP-negative HCC patients [87]. The expression of lncRNA tetraspanin-12 (TSPAN12) was upregulated in HCC with microvascular invasion (MVI) (AUC $=0.855,95 \%$ CI: 0.797-0.912) with a sensitivity and specificity of $76.3 \%$ and $80 \%$, respectively. Furthermore, TSPAN12 is an independent prognostic predictor for overall survival (HR = $2.92495 \%$ CI: 1.460-5.855) [88] In HBV-related HCC patients, the levels of lncRNA semaphorin 6A-antisense RNA 1 (SEMA6A-AS1) were reduced, correlated negatively with AFP levels, and were significantly associated with poor overall survival [89]. The levels of serum Linc00152 and UCA1 were significantly increased in HCC patients, and the panel of serum linc00152, UCA1, and AFP showed significant predictive ability, with an AUC of 0.912 and sensitivity and specificity of $82.9 \%$ and $88.2 \%$, respectively [72]. Serum lncRNA NONHSAT053785 levels, which were significantly upregulated in HCC patients (AUC $=0.801$ ), were higher in HCC patients with intrahepatic metastasis (AUC $=0.678$ ). In addition, NONHSAT053785 could act as an independent predictor of intrahepatic metastasis in the elderly, drinking or non-smoking patients, and patients with tumor size $>5 \mathrm{~cm}$ [96].

Furthermore, circulating miRNAs have also been reported as potential novel biomarkers for HCC diagnosis and prognosis (Table 3). Expression levels of serum miR-21 were significantly higher in HCC patients than in controls with an AUC of 0.849 , a sensitivity of $82.1 \%$, and a specificity of $83.9 \%$; this finding was true even in AFP-negative HCC subgroups, with an AUC of 0.831 , a sensitivity of $81.2 \%$, and a specificity of $83.2 \%$. Additionally, serum levels of miR-21 were significantly associated with distant metastasis [97]. A meta-analysis study found serum miR-122 to be overexpressed in HCC patients with a pooled AUC of 0.82 , a pooled sensitivity of $76 \%$, and a pooled specificity of $75 \%$ [98,99]. The levels of serum exosomal miR-10b-5p and miR-215-5p were significantly higher in HCC patients, and serum exosomal miR-10b-5p could be a diagnostic biomarker for early-stage HCC with an AUC of 0.934 , a sensitivity of $90.7 \%$, and a specificity of $75.0 \%$ (cutoff value 1.8-fold) [102]. Serum exosomal miR-215-5p levels were significantly increased in patients with vascular invasion than in patients without vascular invasion and these higher levels were associated with poor prognosis in patients with HCC [102]. The expression of serum miR-424 was obviously decreased in HCC compared with healthy controls (AUC, 0.768 ), with a sensitivity and specificity of $75.0 \%$ and $72.4 \%$, respectively [104]. Moreover, serum miR-424 levels were significantly correlated with metastasis and vein invasion. [104]. Additionally, circulating miRNA panels also showed good performance as early diagnostic biomarkers of HCC [22,105]. Thus, the combination of lncRNAs, circulat- 
ing miRNAs, and AFP has great promise as a novel strategy with diagnostic and prognostic value for HCC.

\subsection{Effect of IncRNA and miRNA Networks in Therapy Resistance}

The aim of treatment is to prolong survival while maintaining the quality of life. The choice of treatment depends on the stage of diagnosis, commonly resection, ablation, and transplantation for early-stage HCC, transarterial chemoembolization for intermediatestage HCC, and systemic treatments, such as tyrosine kinase inhibitors, chemotherapy agents, and immune checkpoint inhibitors, for advanced-stage HCC [83]. Only a small fraction of patients present with early-stage HCC, whose treatment is limited by the underlying liver disease. In recent years, systemic treatments have been available for advanced-stage HCC patients, but the resistance of agents remains a severe problem [106]. Many studies have indicated that lncRNA and miRNA networks are associated with drug resistance in HCC treatment (Table 4).

The hepatitis B virus-encoded X (HBx) protein upregulated lncRNA TRERNA1 expression and enhanced sorafenib resistance in HBV-HCC. TRERNA1 acts as a ceRNA and sponges miR-22-3p; the potential target of miR-22-3p, NRAS, is then upregulated and activates the RAS/Raf/MEK/ERK signaling pathway [107]. HCC cells with high lncRNA HOTAIR expression enhanced sorafenib resistance by sponging miR-217 [112]. lncRNA MALAT1 is highly expressed in HCC sorafenib-resistant cells and upregulates the expression of Aurora-A by binding to miR-140-5p, thus enhancing sorafenib resistance [105]. Moreover, lncRNA TTN-AS1 [107], SNHG16 [113], and HANR [114] have also been shown to enhance sorafenib resistance. In contrast, the levels of IncRNA FOXD2-AS1 were decreased in sorafenib-resistant cells compared with those in the corresponding parental cells. Overexpression of FOXD2-AS1 upregulated transmembrane protein 9 (TMEM9) expression by binding FOXD2-AS1 to miR-150-5p, and increased sorafenib sensitivity [117]. Lenvatinib, as a multi-tyrosine kinase inhibitor, is also an option in first-line therapy for advanced HCC, but its resistance is still to be addressed. LncRNA MT1JP is overexpressed in lenvatinib-resistant cells; sponging miR-24-3p releases Bcl-2 like 2 (BCL2L2), which inhibits apoptosis and impairs the sensitivity of HCC cells to lenvatinib [118]. Olaparib is a poly ADP ribose polymerase (PARP) inhibitor. LncRNA DUXAP8 enhances resistance to olaparib by sponging miR-485-5p, upregulating forkhead box protein M1 (FOXM1) expression, and interacting with the RNA-binding protein fused in sarcoma (FUS) [119].

Resistance is a major challenge for chemotherapy agents. LncRNA UCA1 binds to miR138-5p and activates the AKT/mTOR signaling pathway [120]. LncRNA NR2F1-AS1, which sponges miR-363, releases ATP binding cassette subfamily A member 1 (ABCA1) [121], which contributes to oxaliplatin resistance in HCC. Overexpression of IncRNA MALAT1 enhances doxorubicin resistance in HCC by mediating the miR-3129-5p/Nova1 axis [122]. lncRNA LEF1-AS1 combined with miR-10a-5p increases musashi1 (MSI1) expression and activates the AKT signaling pathway to stimulate cisplatin resistance in HCC [123]. Moreover, lncRNA LINC01234 enhances melanoma-associated antigen A3 (MAGEA3) expression by binding to miR-31-5p and increasing cisplatin resistance [125]. Nevertheless, upregulated lncRNA GAS5 could enhance cisplatin sensitivity by sponging miR-222 [124]. 
Table 4. LncRNA and miRNA networks in hepatocellular carcinoma therapy resistance.

\begin{tabular}{|c|c|c|c|c|}
\hline Drug & LncRNA & Resistance & Mechanism & References \\
\hline \multirow[t]{12}{*}{ Sorafenib } & $\begin{array}{c}\text { Translation Regulatory Long Non-Coding } \\
\text { RNA } 1 \text { (TRERNA1) }\end{array}$ & enhance & miR-22-3p/NRAS axis & [107] \\
\hline & $\begin{array}{c}\text { Nicotinamide nucleotide transhydrogenase } \\
\text { antisense RNA } 1 \text { (NNT-AS1) }\end{array}$ & enhance & miR-16-5p/cyclin E1 & [108] \\
\hline & $\begin{array}{c}\text { Kcnq1 overlapping transcript } 1 \\
\text { (KCNQ1OT1) }\end{array}$ & enhance & miR-506/ PD-L1 & [109] \\
\hline & POIR & enhance & sponging miR-182-5p & [110] \\
\hline & H19 & enhance & upregulating miR-675 & [111] \\
\hline & $\begin{array}{l}\text { HOX transcript antisense intergenic RNA } \\
\text { (HOTAIR) }\end{array}$ & enhance & sponging miR-217 & [112] \\
\hline & Small nuclear RNA host gene 16 (SNHG16) & enhance & miR-23b-3p/ EGR1 & [113] \\
\hline & MALAT1 & enhance & miR-140-5p/Aurora-A & [114] \\
\hline & $\begin{array}{l}\text { HCC associated long non-coding RNA } \\
\text { (HANR) }\end{array}$ & enhance & miR-29b/ATG9A axis & [115] \\
\hline & $\begin{array}{l}\text { Nuclear paraspeckle assembly transcript } 1 \\
\text { (NEAT1) }\end{array}$ & enhance & miR-204/ATG3 & [116] \\
\hline & $\begin{array}{l}\text { FOXD2 Adjacent Opposite Strand RNA } 1 \\
\text { (FOXD2-AS1) }\end{array}$ & weaken & miR-150-5p/ TMEM9 & [117] \\
\hline & Small nucleolar RNA host gene 3 (SNHG3) & enhance & miR-128/CD151 & [35] \\
\hline Lenvatinib & Metallothionein $1 \mathrm{~J}$, pseudogene (MT1JP) & enhance & miR-24-3p/BCL2L2 axis & [118] \\
\hline Olaparib & $\begin{array}{l}\text { Double homeobox A pseudogene } 8 \\
\text { (DUXAP8) }\end{array}$ & enhance & miR-485-5p/ FOXM1 & [119] \\
\hline \multirow[t]{2}{*}{ Oxaliplatin } & UCA1 & enhance & sponging miR-138-5p & [120] \\
\hline & $\begin{array}{l}\text { Nuclear receptor subfamily } 2 \text { group F } \\
\text { member 1-antisense RNA } 1 \text { (NR2F1-AS1) }\end{array}$ & enhance & miR-363/ABCC1 & [121] \\
\hline Doxorubicin & MALAT1 & enhance & miR-3129-5p/Nova1 axis & [122] \\
\hline \multirow[t]{3}{*}{ Cisplatin } & $\begin{array}{c}\text { Lymphoid enhancer-binding factor } 1 \\
\text { antisense RNA } 1 \text { (LEF1-AS1) }\end{array}$ & enhance & miR-10a-5p/MSI1 & [123] \\
\hline & Growth-arrest-specific transcript 5 (GAS5) & weaken & sponging miR-222 & [124] \\
\hline & LINC01234 & enhance & miR-31-5p/MAGEA3 & [125] \\
\hline
\end{tabular}

Abbreviations: LncRNA, long non-coding RNA; miR, MicroRNA.

\section{LncRNA and miRNA Networks in the Tumor Microenvironment of HCC}

The tumor microenvironment is complex, including that of HCC, involving crosstalk among tumor components such as HCC cells, the surrounding blood vessels, stromal cells, and immune cells, all of which are critical in tumorigenesis, angiogenesis, and metastasis. The immune checkpoint molecules, growth factors, cytokines, chemokines, noncodingRNAs, and metabolites also participate in these interactions [126-128] (Figure 2).

Hypoxia is a crucial feature in solid tumors, including those in HCC, which induces a hypoxic response by upregulating hypoxia-inducible factors (HIFs), especially hypoxiainducible factor $1 \alpha(\mathrm{HIF}-1 \alpha)$. Furthermore, a cascade of metabolic changes in hypoxia facilitates cancer cell proliferation, glycolysis, EMT, drug resistance, and an immunosuppressive tumor microenvironment [129]. Recent studies have indicated that lncRNA and miRNA networks also play a key role in the metabolic changes associated with hypoxia. In HCC, highly expressed lncRNA zinc finger protein multitype 2 antisense RNA 1 (ZFPM2-AS1) [130] and HULC [131] bind to miR-576-3p and miR-377-5p, respectively, to upregulate the expression of HIF-1 $\alpha$. In addition, lncRNA MAPKAPK5-AS1 is significantly overexpressed in HCC and is directly activated by HIF- $1 \alpha$, which negatively regulates miR-154-5p to promote PLAG1 like zinc finger 2 (PLAGL2) expression. PLAGL2 activates the EGFR/AKT signaling pathway and increases the expression of HIF- $1 \alpha$; this positive signaling loop enhances hypoxia, HCC growth, and metastasis [132]. Hypoxia-induced lncRNAs also facilitate HCC proliferation and metastasis. Hypoxia-induced lncRNA NEAT1 [133] and EIF3J antisense RNA 1 (EIF3J-AS1) [134] promote HCC proliferation by 
regulating the miR-199a-3p/ uridine-cytidine kinase 2 (UCK2) and miR-122-5p/ catenin delta 2 (CTNND2) axis, respectively. HIF-1 $\alpha$ activates the transcription of lncRNA retinoic acid early transcript $1 \mathrm{~K}$ (RAET1K), following the highly expressed lncRNA RAET1K sponging miR-100-5p to increase the expression of lactate dehydrogenase A (LDHA), which enhances glycolysis [135]. Overexpressed lncRNA HOTAIR targets miR-130a-3p to increase HIF-1 $\alpha$ expression and glycolysis [136]. Moreover, hypoxia-inducible lncRNA neuropeptide $S$ receptor 1 antisense RNA 1 (NPSR1-AS1) overexpression enhances the expression of p-ERK1/2 and pyruvate kinase M2 (PKM2) and activates the MAPK/ERK pathway to promote the growth and glycolysis of HCC cells [137]. In contrast to the abovementioned lncRNAs, lncRNA carbamoyl-phosphate synthetase 1 intronic transcript 1 (CPS1-IT1) levels were obviously decreased in HCC, while CPS1-IT1 overexpression reduced HIF- $1 \alpha$ activation to inhibit EMT and metastasis [138].

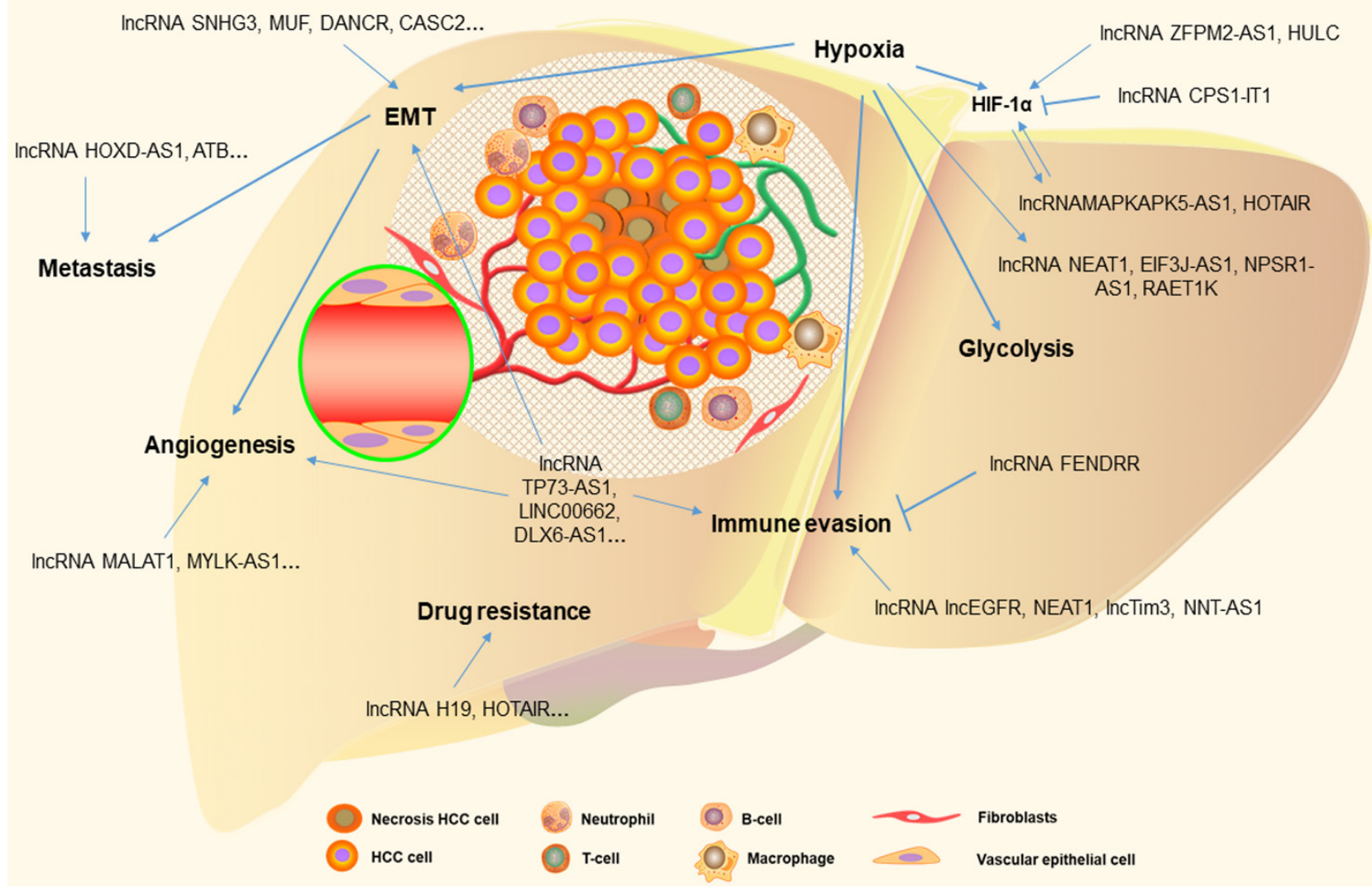

Figure 2. Long non-coding RNAs involved in the complex tumor microenvironment of HCC. LncRNA, long non-coding RNA; EMT, epithelial-mesenchymal transition; HIF-1 $\alpha$, hypoxia-inducible factor $1 \alpha$.

Immune cells in the tumor microenvironment contain regulatory T cells (Treg), CD8+ T cells, CD4+ T cells, myeloid-derived suppressor cells (MDSCs), tumor-associated macrophages (TAMs), natural killer (NK) cells, and cancer-associated fibroblasts (CAFs), which contribute to inducing immune evasion, EMT, and drug resistance. Hypoxia induces an immunosuppressive tumor microenvironment, increasing the number of Treg and MDSC cells, promoting M2 macrophage polarization, and decreasing the number and activity of CD8+ cells and NK cells, which also aids in the immune evasion of tumor cells [129]. lncRNA fetal-lethal noncoding developmental regulatory RNA (FENDRR) inhibits the Treg-mediated immune escape of HCC cells by sponging miR-423-5p to upregulate the levels of growth arrest and the DNA-damage-inducible beta protein (GADD45B) [139]. In contrast, IncRNA IncEGFR stimulates Treg differentiation, inhibits cytotoxic $\mathrm{T}$ lymphocyte (CTL) activity in an EGFR-dependent manner, and promotes HCC immune evasion [140]. lncRNA NEAT1 is increased in the peripheral blood mononuclear cells (PBMCs) of pa- 
tients with HCC, which decreases the antitumor activity of CD8 + T cells against HCC by regulating the miR-155/Tim-3 axis [141]. LncTim3 exacerbates CD8+ T cell exhaustion by specifically binding to Tim-3 [142]. In addition, overexpressed lncRNA TP73-AS1 sponges miR-539 to upregulate matrix metalloproteinase-8 (MMP-8) expression, which activates TGF- $\beta 1$ signaling to induce M2 macrophage polarization in HCC [143]. LINC00662 competitively binds to miR-15a, miR-16, and miR-107 to promote Wnt-3a expression, following activation of the Wnt/ $\beta$-catenin signaling pathway to promote M2 macrophage polarization [32]. HCC-derived exosomal lncRNA DLX6 antisense RNA 1 (DLX6-AS1) induces M2 macrophage polarization and promotes EMT by binding to miR-15a-5p to increase C-X-C motif chemokine ligand 17 (CXCL17) expression [144]. Exosomal lncRNA TUC339 is also involved in the regulation of macrophage polarization [145]. TAMs with M2 polarization contribute to HCC cell proliferation, angiogenesis, EMT, and interaction with other immune cells [146]. Additionally, TAMs are associated with CD8+ T cell conversion to an exhausted phenotype, which may be through the PD-1/PD-L1 and Tim3 signaling pathways [146].

In this complex tumor microenvironment, intercellular signaling communication plays an important role in the regulation of the biological behavior of HCC. Transforming growth factor- $\beta$ (TGF- $\beta$ ) signaling is associated with inflammation, tissue fibrosis, cancer-related metastasis, angiogenesis, and immunosuppression, while activating other signaling pathways, such as extracellular signal-regulated kinase (ERK)/mitogen-activated protein kinase (MAPK) signaling and protein kinase B (Akt) signaling [147]. Overexpressed lncRNA NNT-AS1 decreases tumor CD4 lymphocyte infiltration by activating the TGF- $\beta$ signaling pathway in HCC [148]. The lncRNA MEG8 promotes HCC progression via the miR-367-3p/14-3-3乙/TGF $\beta-R 1$ axis [149]. LncRNA DLGAP1 antisense RNA 1 (D LGAP1-AS1) binds to miR-26a/b-5p to enhance the levels of interleukin-6 (IL-6), cyclin-dependent kinase 8 (CDK8), and low-density lipoprotein receptor-related protein 6 (LRP6), which activates the JAK2/STAT3 and Wnt/ $\beta$-catenin signaling pathways, respectively, to facilitate tumorigenesis and EMT [150]. However, lncRNA TSLNC8 acts as a tumor inhibitor to suppress the IL-6/STAT3 signaling pathway [151]. Furthermore, lncRNA MALAT1 [152] targets miR-140 to upregulate VEGF-A expression and lncRNA MYLK Antisense RNA 1 (MYLK-AS1) [48] binds to miR-424-5p to increase the levels of E2F transcription factor 7 (E2F7) to activate the VEGFR-2 signaling pathway, which facilitates HCC progression and angiogenesis.

\section{Conclusions and Perspectives}

A growing number of lncRNAs and miRNAs have been identified to play key roles in regulating HCC progression. The regulatory effect of miRNA occurs via binding to the $3^{\prime}$-UTR of target mRNAs, while lncRNAs are mainly sponges of miRNAs in the lncRNA and miRNA network, which is one of the critical lncRNA action modes, directly and indirectly, that modulates target gene expression, usually as the lncRNA-miRNA-mRNA axis. In the present review, we summarized the functional roles and related target genes of the lncRNA and miRNA networks. The dominant lncRNAs are oncogenic or suppressor lncRNAs in tumorigenesis and the progression of HCC. The dysregulated expression of lncRNAs contributes to clinical diagnosis and prognosis prediction as potential biomarkers. Additionally, lncRNA and miRNA networks are involved in the regulation of the tumor microenvironment, including EMT, hypoxia, glycolysis, and immune evasion.

In the tumor microenvironment, hypoxia promotes glycolysis, EMT, and the formation of an immunosuppressive microenvironment. Simultaneously, the promotor lncRNAs could enhance hypoxia in a positive signaling loop, inducing M2 macrophage polarization to promote EMT and aggravating immune evasion. The interaction of tumor microenvironment components continues to deteriorate the microenvironment and facilitate HCC progression. However, there are limited studies on lncRNA inhibitors in the tumor microenvironment.

To date, most of the studies remain at the basic research stage, and little evidence regarding the clinical applications of lncRNAs or miRNAs has been presented (Table 5). As mentioned in the present review, lncRNA HOTAIR, MALAT1, and H19 play critical roles in 
HCC growth, angiogenesis, and resistance and may represent excellent therapeutic targets. However, as for miRNAs [153,154], a number of questions and challenges still exist for lncRNAs. First, in terms of on-target specificity, the efficacy of therapy may vary depending on the cell type. Second, efficient delivery, specific controlled delivery, and safety are the key points of lncRNA-based therapies. Lipid nanoparticles, polymers, RNA conjugations, and virus-based delivery have been used in clinically approved therapeutics or clinical testing. Additionally, exosome-mediated delivery, bacteriophages, and bacterial minicell delivery vehicles are still being developed. Third, efficacious doses and pharmacokinetics remain obstacles for development $[155,156]$. Further research and analyses of lncRNAs and miRNAs will provide more evidence and novel insights into the pathogenesis of HCC, which contributes to the diagnosis, therapy, and prognosis prediction of HCC.

Table 5. LncRNA-based or miRNA-based therapy clinical trials in cancer.

\begin{tabular}{|c|c|c|c|c|c|c|}
\hline $\begin{array}{l}\text { Registration } \\
\text { Number }\end{array}$ & Phase & Regimen & Target & Target Population & Result & Reference \\
\hline NCT03719300 & Phase 2 & BC-819 & $\begin{array}{l}\text { IncRNA } \\
\text { H19 }\end{array}$ & $\begin{array}{l}\text { Non-muscle Invasive } \\
\text { Bladder Cancer }\end{array}$ & Lack of efficacy & \\
\hline NCT01829971 & Phase 1 & MRX34 & miR-34 & $\begin{array}{l}\text { Primary Liver Cancer, } \\
\text { SCLC, Lymphoma, } \\
\text { Melanoma, } \\
\text { Multiple Myeloma, } \\
\text { Renal Cell Carcinoma, } \\
\text { NSCLC }\end{array}$ & $\begin{array}{l}\text { Early terminated (Five } \\
\text { immune related } \\
\text { serious adverse events) }\end{array}$ & [157] \\
\hline NCT02369198 & Phase 1 & TargomiRs & miR-16 & $\begin{array}{c}\text { Malignant Pleural } \\
\text { Mesothelioma, NSCLC }\end{array}$ & ORR: $5 \%$, SD: $68 \%$ & [158] \\
\hline NCT02580552 & Phase 1 & Cobomarsen & miR-155 & $\begin{array}{c}\text { Cutaneous T-cell } \\
\text { Lymphoma, } \\
\text { Mycosis Fungoides, } \\
\text { Chronic Lymphocytic } \\
\text { Leukemia, Diffuse Large } \\
\text { B-Cell Lymphoma (ABC } \\
\text { Subtype), Adult T-Cell } \\
\text { Leukemia/Lymphoma }\end{array}$ & Completed & \\
\hline NCT03713320 & Phase 2 & Cobomarsen & miR-155 & $\begin{array}{l}\text { Cutaneous T-Cell } \\
\text { Lymphoma/Mycosis } \\
\text { Fungoides }\end{array}$ & $\begin{array}{l}\text { Early terminated for } \\
\text { business reasons, and } \\
\text { not due to concerns } \\
\text { regarding safety or lack } \\
\text { of efficacy }\end{array}$ & \\
\hline
\end{tabular}

Abbreviations: LncRNA, long non-coding RNA; miR, MicroRNA; NSCLC, non-small cell lung cancer; ORR, objective response rate; SCLC, small-cell lung cancer; SD, stable disease.

Author Contributions: T.S. and T.M. conceived and designed the study. T.S., H.K. and A.M. collected the data. T.S. wrote the manuscript. T.S. and T.M. edited the manuscript. All authors have read and agreed to the published version of the manuscript.

Funding: This research received no external funding.

Institutional Review Board Statement: Not applicable.

Informed Consent Statement: Not applicable.

Data Availability Statement: Not applicable.

Conflicts of Interest: The authors declare no conflict of interest. 


\section{References}

1. Sung, H.; Ferlay, J.; Siegel, R.L.; Laversanne, M.; Soerjomataram, I.; Jemal, A.; Bray, F. Global Cancer Statistics 2020: GLOBOCAN Estimates of Incidence and Mortality Worldwide for 36 Cancers in 185 Countries. CA Cancer J. Clin. 2021, 71, 209-249. [CrossRef]

2. Yang, J.D.; Hainaut, P.; Gores, G.J.; Amadou, A.; Plymoth, A.; Roberts, L.R. A global view of hepatocellular carcinoma: Trends, risk, prevention and management. Nat. Rev. Gastroenterol. Hepatol. 2019, 16, 589-604. [CrossRef] [PubMed]

3. Roehlen, N.; Crouchet, E.; Baumert, T.F. Liver Fibrosis: Mechanistic Concepts and Therapeutic Perspectives. Cells 2020, 9 , 875. [CrossRef]

4. Shi, T.; Kobara, H.; Oura, K.; Masaki, T. Mechanisms Underlying Hepatocellular Carcinoma Progression in Patients with Type 2 Diabetes. J. Hepatocell Carcinoma 2021, 8, 45-55. [CrossRef] [PubMed]

5. Kudo, M.; Finn, R.S.; Qin, S.; Han, K.H.; Ikeda, K.; Piscaglia, F.; Baron, A.; Park, J.W.; Han, G.; Jassem, J.; et al. Lenvatinib versus sorafenib in first-line treatment of patients with unresectable hepatocellular carcinoma: A randomised phase 3 non-inferiority trial. Lancet 2018, 391, 1163-1173. [CrossRef]

6. Altekruse, S.F.; McGlynn, K.A.; Dickie, L.A.; Kleiner, D.E. Hepatocellular carcinoma confirmation, treatment, and survival in surveillance, epidemiology, and end results registries, 1992-2008. Hepatology 2012, 55, 476-482. [CrossRef] [PubMed]

7. Lee, Y.S.; Dutta, A. MicroRNAs in cancer. Annu. Rev. Pathol. 2009, 4, 199-227. [CrossRef]

8. Yu, J.; Wang, F.; Yang, G.H.; Wang, F.L.; Ma, Y.N.; Du, Z.W.; Zhang, J.W. Human microRNA clusters: Genomic organization and expression profile in leukemia cell lines. Biochem. Biophys. Res. Commun. 2006, 349, 59-68. [CrossRef]

9. Cozar, J.M.; Robles-Fernandez, I.; Rodriguez-Martinez, A.; Puche-Sanz, I.; Vazquez-Alonso, F.; Lorente, J.A.; Martinez-Gonzalez, L.J.; Alvarez-Cubero, M.J. The role of miRNAs as biomarkers in prostate cancer. Mutat. Res. 2019, 781, 165-174. [CrossRef]

10. Yao, R.W.; Wang, Y.; Chen, L.L. Cellular functions of long noncoding RNAs. Nat. Cell Biol. 2019, 21, 542-551. [CrossRef]

11. Chi, Y.; Wang, D.; Wang, J.; Yu, W.; Yang, J. Long Non-Coding RNA in the Pathogenesis of Cancers. Cells 2019, 8, 1015. [CrossRef]

12. Guttman, M.; Rinn, J.L. Modular regulatory principles of large non-coding RNAs. Nature 2012, 482, 339-346. [CrossRef]

13. Wang, K.C.; Chang, H.Y. Molecular mechanisms of long noncoding RNAs. Mol. Cell 2011, 43, 904-914. [CrossRef]

14. Cheng, J.T.; Wang, L.; Wang, H.; Tang, F.R.; Cai, W.Q.; Sethi, G.; Xin, H.W.; Ma, Z. Insights into Biological Role of LncRNAs in Epithelial-Mesenchymal Transition. Cells 2019, 8, 1178. [CrossRef]

15. Kosaka, N.; Kogure, A.; Yamamoto, T.; Urabe, F.; Usuba, W.; Prieto-Vila, M.; Ochiya, T. Exploiting the message from cancer: The diagnostic value of extracellular vesicles for clinical applications. Exp. Mol. Med. 2019, 51, 1-9. [CrossRef] [PubMed]

16. Qin, G.; Tu, X.; Li, H.; Cao, P.; Chen, X.; Song, J.; Han, H.; Li, Y.; Guo, B.; Yang, L.; et al. Long Noncoding RNA p53-Stabilizing and Activating RNA Promotes p53 Signaling by Inhibiting Heterogeneous Nuclear Ribonucleoprotein K deSUMOylation and Suppresses Hepatocellular Carcinoma. Hepatology 2020, 71, 112-129. [CrossRef] [PubMed]

17. Salerno, D.; Chiodo, L.; Alfano, V.; Floriot, O.; Cottone, G.; Paturel, A.; Pallocca, M.; Plissonnier, M.L.; Jeddari, S.; Belloni, L.; et al. Hepatitis B protein HBx binds the DLEU2 lncRNA to sustain cccDNA and host cancer-related gene transcription. Gut 2020, 69, 2016-2024. [CrossRef]

18. Rybakova, Y.; Gonzalez, J.T.; Bogorad, R.; Chauhan, V.P.; Dong, Y.L.; Whittaker, C.A.; Zatsepin, T.; Koteliansky, V.; Anderson, D.G. Identification of a long non-coding RNA regulator of liver carcinoma cell survival. Cell Death Dis. 2021, 12, 178. [CrossRef]

19. Khorkova, O.; Hsiao, J.; Wahlestedt, C. Basic biology and therapeutic implications of lncRNA. Adv. Drug Deliv. Rev. 2015, 87, 15-24. [CrossRef] [PubMed]

20. Fernandes, J.C.R.; Acuña, S.M.; Aoki, J.I.; Floeter-Winter, L.M.; Muxel, S.M. Long Non-Coding RNAs in the Regulation of Gene Expression: Physiology and Disease. Noncoding RNA 2019, 5, 17. [CrossRef] [PubMed]

21. Yao, Y.; Ma, J.; Xue, Y.; Wang, P.; Li, Z.; Liu, J.; Chen, L.; Xi, Z.; Teng, H.; Wang, Z.; et al. Knockdown of long non-coding RNA XIST exerts tumor-suppressive functions in human glioblastoma stem cells by up-regulating miR-152. Cancer Lett. 2015, 359, 75-86. [CrossRef] [PubMed]

22. Morishita, A.; Oura, K.; Tadokoro, T.; Fujita, K.; Tani, J.; Masaki, T. MicroRNAs in the Pathogenesis of Hepatocellular Carcinoma: A Review. Cancers 2021, 13, 514. [CrossRef] [PubMed]

23. Huang, X.; Gao, Y.; Qin, J.; Lu, S. lncRNA MIAT promotes proliferation and invasion of HCC cells via sponging miR-214. Am. J. Physiol. Gastrointest. Liver Physiol. 2018, 314, G559-G565. [CrossRef] [PubMed]

24. Zhao, L.; Hu, K.; Cao, J.; Wang, P.; Li, J.; Zeng, K.; He, X.; Tu, P.F.; Tong, T.; Han, L. lncRNA miat functions as a ceRNA to upregulate sirt1 by sponging miR-22-3p in HCC cellular senescence. Aging 2019, 11, 7098-7122. [CrossRef] [PubMed]

25. Wang, Y.; Yang, L.; Chen, T.; Liu, X.; Guo, Y.; Zhu, Q.; Tong, X.; Yang, W.; Xu, Q.; Huang, D.; et al. A novel lncRNA MCM3AP-AS1 promotes the growth of hepatocellular carcinoma by targeting miR-194-5p/FOXA1 axis. Mol. Cancer 2019, 18, 28. [CrossRef]

26. Wang, H.; Huo, X.; Yang, X.R.; He, J.; Cheng, L.; Wang, N.; Deng, X.; Jin, H.; Wang, N.; Wang, C.; et al. STAT3-mediated upregulation of lncRNA HOXD-AS1 as a ceRNA facilitates liver cancer metastasis by regulating SOX4. Mol. Cancer 2017, 16, 136. [CrossRef]

27. Lu, S.; Zhou, J.; Sun, Y.; Li, N.; Miao, M.; Jiao, B.; Chen, H. The noncoding RNA HOXD-AS1 is a critical regulator of the metastasis and apoptosis phenotype in human hepatocellular carcinoma. Mol. Cancer 2017, 16, 125. [CrossRef]

28. Xiong, H.; Ni, Z.; He, J.; Jiang, S.; Li, X.; He, J.; Gong, W.; Zheng, L.; Chen, S.; Li, B.; et al. LncRNA HULC triggers autophagy via stabilizing Sirt1 and attenuates the chemosensitivity of HCC cells. Oncogene 2017, 36, 3528-3540. [CrossRef] 
29. Chen, J.; Huang, X.; Wang, W.; Xie, H.; Li, J.; Hu, Z.; Zheng, Z.; Li, H.; Teng, L. LncRNA CDKN2BAS predicts poor prognosis in patients with hepatocellular carcinoma and promotes metastasis via the miR-153-5p/ARHGAP18 signaling axis. Aging 2018, 10, 3371-3381. [CrossRef]

30. Li, B.; Mao, R.; Liu, C.; Zhang, W.; Tang, Y.; Guo, Z. LncRNA FAL1 promotes cell proliferation and migration by acting as a CeRNA of miR-1236 in hepatocellular carcinoma cells. Life Sci. 2018, 197, 122-129. [CrossRef]

31. Yuan, J.H.; Yang, F.; Wang, F.; Ma, J.Z.; Guo, Y.J.; Tao, Q.F.; Liu, F.; Pan, W.; Wang, T.T.; Zhou, C.C.; et al. A long noncoding RNA activated by TGF- $\beta$ promotes the invasion-metastasis cascade in hepatocellular carcinoma. Cancer Cell 2014, 25, 666-681. [CrossRef] [PubMed]

32. Tian, X.; Wu, Y.; Yang, Y.; Wang, J.; Niu, M.; Gao, S.; Qin, T.; Bao, D. Long noncoding RNA LINC00662 promotes M2 macrophage polarization and hepatocellular carcinoma progression via activating Wnt/ $\beta$-catenin signaling. Mol. Oncol. 2020, 14, 462-483. [CrossRef] [PubMed]

33. Lu, Z.; Yu, Y.; Ding, X.; Jin, D.; Wang, G.; Zhou, Y.; Zhu, Y.; Na, L.; He, Y.; Wang, Q. LncRNA FLJ33360 accelerates the metastasis in hepatocellular carcinoma by targeting miRNA-140/MMP9 axis. Am. J. Transl. Res. 2020, 12, 583-591. [PubMed]

34. Zuo, X.; Chen, Z.; Gao, W.; Zhang, Y.; Wang, J.; Wang, J.; Cao, M.; Cai, J.; Wu, J.; Wang, X. M6A-mediated upregulation of LINC00958 increases lipogenesis and acts as a nanotherapeutic target in hepatocellular carcinoma. J. Hematol. Oncol. 2020, 13, 5. [CrossRef]

35. Zhang, P.F.; Wang, F.; Wu, J.; Wu, Y.; Huang, W.; Liu, D.; Huang, X.Y.; Zhang, X.M.; Ke, A.W. LncRNA SNHG3 induces EMT and sorafenib resistance by modulating the miR-128/CD151 pathway in hepatocellular carcinoma. J. Cell Physiol. 2019, 234, 2788-2794. [CrossRef]

36. Ye, Y.; Guo, J.; Xiao, P.; Ning, J.; Zhang, R.; Liu, P.; Yu, W.; Xu, L.; Zhao, Y.; Yu, J. Macrophages-induced long noncoding RNA H19 up-regulation triggers and activates the miR-193b/MAPK1 axis and promotes cell aggressiveness in hepatocellular carcinoma. Cancer Lett. 2020, 469, 310-322. [CrossRef]

37. Yan, X.; Zhang, D.; Wu, W.; Wu, S.; Qian, J.; Hao, Y.; Yan, F.; Zhu, P.; Wu, J.; Huang, G.; et al. Mesenchymal Stem Cells Promote Hepatocarcinogenesis via lncRNA-MUF Interaction with ANXA2 and miR-34a. Cancer Res. 2017, 77, 6704-6716. [CrossRef]

38. Liu, X.; Liang, Y.; Song, R.; Yang, G.; Han, J.; Lan, Y.; Pan, S.; Zhu, M.; Liu, Y.; Wang, Y.; et al. Long non-coding RNA NEAT1modulated abnormal lipolysis via ATGL drives hepatocellular carcinoma proliferation. Mol. Cancer 2018, 17, 90. [CrossRef]

39. Guo, D.; Li, Y.; Chen, Y.; Zhang, D.; Wang, X.; Lu, G.; Ren, M.; Lu, X.; He, S. DANCR promotes HCC progression and regulates EMT by sponging miR-27a-3p via ROCK1/LIMK1/COFILIN1 pathway. Cell Prolif. 2019, 52, e12628. [CrossRef]

40. Yuan, S.X.; Wang, J.; Yang, F.; Tao, Q.F.; Zhang, J.; Wang, L.L.; Yang, Y.; Liu, H.; Wang, Z.G.; Xu, Q.G.; et al. Long noncoding RNA DANCR increases stemness features of hepatocellular carcinoma by derepression of CTNNB1. Hepatology 2016, 63, 499-511. [CrossRef]

41. Li, Z.; Wu, G.; Li, J.; Wang, Y.; Ju, X.; Jiang, W. lncRNA CRNDE promotes the proliferation and metastasis by acting as sponge miR-539-5p to regulate POU2F1 expression in HCC. BMC Cancer 2020, 20, 282. [CrossRef]

42. Liu, Z.; Wang, Y.; Wang, L.; Yao, B.; Sun, L.; Liu, R.; Chen, T.; Niu, Y.; Tu, K.; Liu, Q. Long non-coding RNA AGAP2AS1, functioning as a competitive endogenous RNA, upregulates ANXA11 expression by sponging miR-16-5p and promotes proliferation and metastasis in hepatocellular carcinoma. J. Exp. Clin. Cancer Res. 2019, 38, 194. [CrossRef]

43. Huang, Y.; Xiang, B.; Liu, Y.; Wang, Y.; Kan, H. LncRNA CDKN2B-AS1 promotes tumor growth and metastasis of human hepatocellular carcinoma by targeting let-7c-5p/NAP1L1 axis. Cancer Lett. 2018, 437, 56-66. [CrossRef]

44. Liu, C.; Wang, H.; Tang, L.; Huang, H.; Xu, M.; Lin, Y.; Zhou, L.; Ho, L.; Lu, J.; Ai, X. LncRNA BACE1-AS enhances the invasive and metastatic capacity of hepatocellular carcinoma cells through mediating miR-377-3p/CELF1 axis. Life Sci. 2021, 275, 119288. [CrossRef]

45. Huang, W.; Huang, F.; Lei, Z.; Luo, H. LncRNA SNHG11 Promotes Proliferation, Migration, Apoptosis, and Autophagy by Regulating hsa-miR-184/AGO2 in HCC. Onco. Targets Ther. 2020, 13, 413-421. [CrossRef]

46. Gong, D.; Feng, P.C.; Ke, X.F.; Kuang, H.L.; Pan, L.L.; Ye, Q.; Wu, J.B. Silencing Long Non-coding RNA LINC01224 Inhibits Hepatocellular Carcinoma Progression via MicroRNA-330-5p-Induced Inhibition of CHEK1. Mol. Ther. Nucleic. Acids 2020, 19, 482-497. [CrossRef] [PubMed]

47. Liu, Z.; Mo, H.; Sun, L.; Wang, L.; Chen, T.; Yao, B.; Liu, R.; Niu, Y.; Tu, K.; Xu, Q.; et al. Long noncoding RNA PICSAR/miR588/EIF6 axis regulates tumorigenesis of hepatocellular carcinoma by activating PI3K/AKT/mTOR signaling pathway. Cancer Sci. 2020, 111, 4118-4128. [CrossRef] [PubMed]

48. Teng, F.; Zhang, J.X.; Chang, Q.M.; Wu, X.B.; Tang, W.G.; Wang, J.F.; Feng, J.F.; Zhang, Z.P.; Hu, Z.Q. LncRNA MYLK-AS1 facilitates tumor progression and angiogenesis by targeting miR-424-5p/E2F7 axis and activating VEGFR-2 signaling pathway in hepatocellular carcinoma. J. Exp. Clin. Cancer Res. 2020, 39, 235. [CrossRef] [PubMed]

49. Zhang, X.; Xu, S.; Hu, C.; Fang, K.; Zhou, J.; Guo, Z.; Zhu, G.; Li, L. LncRNA ST8SIA6-AS1 promotes hepatocellular carcinoma progression by regulating MAGEA3 and DCAF4L2 expression. Biochem. Biophys. Res. Commun. 2020, 533, 1039-1047. [CrossRef]

50. Hu, Y.L.; Feng, Y.; Chen, Y.Y.; Liu, J.Z.; Su, Y.; Li, P.; Huang, H.; Mao, Q.S.; Xue, W.J. SNHG16/miR-605-3p/TRAF6/NF-kB feedback loop regulates hepatocellular carcinoma metastasis. J. Cell Mol. Med. 2020, 24, 7637-7651. [CrossRef]

51. Fan, J.; Zhang, J.; Huang, S.; Li, P. lncRNA OSER1-AS1 acts as a ceRNA to promote tumorigenesis in hepatocellular carcinoma by regulating miR-372-3p/Rab23 axis. Biochem. Biophys. Res. Commun. 2020, 521, 196-203. [CrossRef] 
52. Hong, H.; Sui, C.; Qian, T.; Xu, X.; Zhu, X.; Fei, Q.; Yang, J.; Xu, M. Long noncoding RNA LINC00460 conduces to tumor growth and metastasis of hepatocellular carcinoma through miR-342-3p-dependent AGR2 up-regulation. Aging 2020, 12, 10544-10555. [CrossRef]

53. Xuan, W.; Zhou, C.; You, G. LncRNA LINC00668 promotes cell proliferation, migration, invasion ability and EMT process in hepatocellular carcinoma by targeting miR-532-5p/YY1 axis. Biosci. Rep. 2020, 40, BSR20192697. [CrossRef] [PubMed]

54. Liu, S.; Qiu, J.; He, G.; Liang, Y.; Wang, L.; Liu, C.; Pan, H. LncRNA MALAT1 acts as a miR-125a-3p sponge to regulate FOXM1 expression and promote hepatocellular carcinoma progression. J. Cancer 2019, 10, 6649-6659. [CrossRef] [PubMed]

55. Ma, P.; Wang, H.; Sun, J.; Liu, H.; Zheng, C.; Zhou, X.; Lu, Z. LINC00152 promotes cell cycle progression in hepatocellular carcinoma via miR-193a/b-3p/CCND1 axis. Cell Cycle 2018, 17, 974-984. [CrossRef] [PubMed]

56. Wang, Y.; Liu, Z.; Yao, B.; Li, Q.; Wang, L.; Wang, C.; Dou, C.; Xu, M.; Liu, Q.; Tu, K. Long non-coding RNA CASC2 suppresses epithelial-mesenchymal transition of hepatocellular carcinoma cells through CASC2/miR-367/FBXW7 axis. Mol. Cancer 2017, 16, 123. [CrossRef] [PubMed]

57. Wang, Y.G.; Wang, T.; Shi, M.; Zhai, B. Long noncoding RNA EPB41L4A-AS2 inhibits hepatocellular carcinoma development by sponging miR-301a-5p and targeting FOXL1. J. Exp. Clin. Cancer Res. 2019, 38, 153. [CrossRef]

58. Luo, L.H.; Jin, M.; Wang, L.Q.; Xu, G.J.; Lin, Z.Y.; Yu, D.D.; Yang, S.L.; Ran, R.Z.; Wu, G.; Zhang, T. Long noncoding RNA TCL6 binds to miR-106a-5p to regulate hepatocellular carcinoma cells through PI3K/AKT signaling pathway. J. Cell Physiol. 2020, 235, 6154-6166. [CrossRef]

59. Wu, J.; Pang, R.; Li, M.; Chen, B.; Huang, J.; Zhu, Y. m6A-Induced LncRNA MEG3 Suppresses the Proliferation, Migration and Invasion of Hepatocellular Carcinoma Cell Through miR-544b/BTG2 Signaling. Onco Targets 2021, 14, 3745-3755. [CrossRef]

60. Yin, Z.; Ma, T.; Yan, J.; Shi, N.; Zhang, C.; Lu, X.; Hou, B.; Jian, Z. LncRNA MAGI2-AS3 inhibits hepatocellular carcinoma cell proliferation and migration by targeting the miR-374b-5p/SMG1 signaling pathway. J. Cell. Physiol. 2019, 234, 18825-18836. [CrossRef]

61. Wang, S.; Xu, M.; Sun, Z.; Yu, X.; Deng, Y.; Chang, H. LINC01018 confers a novel tumor suppressor role in hepatocellular carcinoma through sponging microRNA-182-5p. Am. J. Physiol. Gastrointest. Liver Physiol. 2019, 317, G116-G126. [CrossRef] [PubMed]

62. Wang, Y.G.; Liu, J.; Shi, M.; Chen, F.X. LncRNA DGCR5 represses the development of hepatocellular carcinoma by targeting the miR-346/KLF14 axis. J. Cell Physiol. 2018, 234, 572-580. [CrossRef] [PubMed]

63. Yan, S.; Tang, Z.; Chen, K.; Liu, Y.; Yu, G.; Chen, Q.; Dang, H.; Chen, F.; Ling, J.; Zhu, L.; et al. Long noncoding RNA MIR31HG inhibits hepatocellular carcinoma proliferation and metastasis by sponging microRNA-575 to modulate ST7L expression. J. Exp. Clin. Cancer Res. 2018, 37, 214. [CrossRef] [PubMed]

64. Lin, S.L.; Lin, Y.H.; Chi, H.C.; Lin, T.K.; Chen, W.J.; Yeh, C.T.; Lin, K.H. A Novel Long Non-Coding RNA-01488 Suppressed Metastasis and Tumorigenesis by Inducing miRNAs That Reduce Vimentin Expression and Ubiquitination of Cyclin, E. Cells 2020, 9, 1504. [CrossRef] [PubMed]

65. Hu, B.; Cai, H.; Zheng, R.; Yang, S.; Zhou, Z.; Tu, J. Long non-coding RNA 657 suppresses hepatocellular carcinoma cell growth by acting as a molecular sponge of miR-106a-5p to regulate PTEN expression. Int. J. Biochem. Cell Biol. 2017, 92, 34-42. [CrossRef]

66. Wang, Y.; Liu, Z.; Yao, B.; Dou, C.; Xu, M.; Xue, Y.; Ding, L.; Jia, Y.; Zhang, H.; Li, Q.; et al. Long non-coding RNA TUSC7 acts a molecular sponge for miR-10a and suppresses EMT in hepatocellular carcinoma. Tumour. Biol. 2016, 37, 11429-11441. [CrossRef]

67. Wu, Y.; Zhou, Y.; Huan, L.; Xu, L.; Shen, M.; Huang, S.; Liang, L. LncRNA MIR22HG inhibits growth, migration and invasion through regulating the miR-10a-5p/NCOR2 axis in hepatocellular carcinoma cells. Cancer Sci. 2019, 110, 973-984. [CrossRef]

68. Duan, R.; Du, W.; Guo, W. EZH2: A novel target for cancer treatment. J. Hematol. Oncol. 2020, 13, 104. [CrossRef]

69. Zhang, K.; Fang, T.; Shao, Y.; Wu, Y. TGF- $\beta$-MTA1-SMAD7-SMAD3-SOX4-EZH2 Signaling Axis Promotes Viability, Migration, Invasion and EMT of Hepatocellular Carcinoma Cells. Cancer Manag. Res. 2021, 13, 7087-7099. [CrossRef]

70. Kotiyal, S.; Evason, K.J. Exploring the Interplay of Telomerase Reverse Transcriptase and $\beta$-Catenin in Hepatocellular Carcinoma Cancers 2021, 13, 4202. [CrossRef]

71. Sun, J.; Guo, Y.; Bie, B.; Zhu, M.; Tian, H.; Tian, J.; Li, J.; Yang, Y.; Ji, F.; Kong, G.; et al. Silencing of long noncoding RNA HOXD-AS1 inhibits proliferation, cell cycle progression, migration and invasion of hepatocellular carcinoma cells through MEK/ERK pathway. J. Cell Biochem. 2020, 121, 443-457. [CrossRef]

72. Huang, J.; Zheng, Y.; Xiao, X.; Liu, C.; Lin, J.; Zheng, S.; Yang, B.; Ou, Q. A Circulating Long Noncoding RNA Panel Serves as a Diagnostic Marker for Hepatocellular Carcinoma. Dis. Markers 2020, 2020, 5417598. [CrossRef] [PubMed]

73. Liu, Y.; Feng, J.; Sun, M.; Yang, G.; Yuan, H.; Wang, Y.; Bu, Y.; Zhao, M.; Zhang, S.; Zhang, X. Long non-coding RNA HULC activates HBV by modulating HBx/STAT3/miR-539/APOBEC3B signaling in HBV-related hepatocellular carcinoma. Cancer Lett. 2019, 454, 158-170. [CrossRef]

74. Li, S.P.; Xu, H.X.; Yu, Y.; He, J.D.; Wang, Z.; Xu, Y.J.; Wang, C.Y.; Zhang, H.M.; Zhang, R.X.; Zhang, J.J.; et al. LncRNA HULC enhances epithelial-mesenchymal transition to promote tumorigenesis and metastasis of hepatocellular carcinoma via the miR-200a-3p/ZEB1 signaling pathway. Oncotarget 2016, 7, 42431-42446. [CrossRef] [PubMed]

75. Malakar, P.; Stein, I.; Saragovi, A.; Winkler, R.; Stern-Ginossar, N.; Berger, M.; Pikarsky, E.; Karni, R. Long Noncoding RNA MALAT1 Regulates Cancer Glucose Metabolism by Enhancing mTOR-Mediated Translation of TCF7L2. Cancer Res. 2019, 79, 2480-2493. [CrossRef] [PubMed]

76. Wang, F.; Ying, H.Q.; He, B.S.; Pan, Y.Q.; Deng, Q.W.; Sun, H.L.; Chen, J.; Liu, X.; Wang, S.K. Upregulated lncRNA-UCA1 contributes to progression of hepatocellular carcinoma through inhibition of miR-216b and activation of FGFR1/ERK signaling pathway. Oncotarget 2015, 6, 7899-7917. [CrossRef] [PubMed] 
77. Liu, Z.; Dang, C.; Xing, E.; Zhao, M.; Shi, L.; Sun, J. Overexpression of CASC2 Improves Cisplatin Sensitivity in Hepatocellular Carcinoma Through Sponging miR-222. DNA Cell Biol. 2019, 38, 1366-1373. [CrossRef] [PubMed]

78. Huang, R.; Wang, X.; Zhang, W.; Zhangyuan, G.; Jin, K.; Yu, W.; Xie, Y.; Xu, X.; Wang, H.; Sun, B. Down-Regulation of LncRNA DGCR5 Correlates with Poor Prognosis in Hepatocellular Carcinoma. Cell Physiol. Biochem. 2016, 40, 707-715. [CrossRef] [PubMed]

79. Qu, C.; He, D.; Lu, X.; Dong, L.; Zhu, Y.; Zhao, Q.; Jiang, X.; Chang, P.; Jiang, X.; Wang, L.; et al. Salt-inducible Kinase (SIK1) regulates HCC progression and WNT/ $\beta$-catenin activation. J. Hepatol. 2016, 64, 1076-1089. [CrossRef] [PubMed]

80. Zhang, D.Y.; Zou, X.J.; Cao, C.H.; Zhang, T.; Lei, L.; Qi, X.L.; Liu, L.; Wu, D.H. Identification and Functional Characterization of Long Non-coding RNA MIR22HG as a Tumor Suppressor for Hepatocellular Carcinoma. Theranostics 2018, 8, 3751-3765. [CrossRef]

81. Jin, Q.; Hu, H.; Yan, S.; Jin, L.; Pan, Y.; Li, X.; Peng, Y.; Cao, P. IncRNA MIR22HG-Derived miR-22-5p Enhances the Radiosensitivity of Hepatocellular Carcinoma by Increasing Histone Acetylation Through the Inhibition of HDAC2 Activity. Front. Oncol. 2021, 11, 572585. [CrossRef] [PubMed]

82. Singal, A.G.; Lampertico, P.; Nahon, P. Epidemiology and surveillance for hepatocellular carcinoma: New trends. J. Hepatol. 2020, 72, 250-261. [CrossRef] [PubMed]

83. Forner, A.; Reig, M.; Bruix, J. Hepatocellular carcinoma. Lancet 2018, 391, 1301-1314. [CrossRef]

84. Tzartzeva, K.; Obi, J.; Rich, N.E.; Parikh, N.D.; Marrero, J.A.; Yopp, A.; Waljee, A.K.; Singal, A.G. Surveillance Imaging and Alpha Fetoprotein for Early Detection of Hepatocellular Carcinoma in Patients With Cirrhosis: A Meta-analysis. Gastroenterology 2018, 154, 1706-1718.e1. [CrossRef]

85. Zhang, B.H.; Yang, B.H.; Tang, Z.Y. Randomized controlled trial of screening for hepatocellular carcinoma. J. Cancer Res. Clin. Oncol. 2004, 130, 417-422. [CrossRef]

86. Luo, P.; Liang, C.; Zhang, X.; Liu, X.; Wang, Y.; Wu, M.; Feng, X.; Tu, J. Identification of long non-coding RNA ZFAS1 as a novel biomarker for diagnosis of HCC. Biosci. Rep. 2018, 38, BSR20171359. [CrossRef]

87. Kim, S.S.; Baek, G.O.; Ahn, H.R.; Sung, S.; Seo, C.W.; Cho, H.J.; Nam, S.W.; Cheong, J.Y.; Eun, J.W. Serum small extracellular vesiclederived LINC00853 as a novel diagnostic marker for early hepatocellular carcinoma. Mol. Oncol. 2020, 14, 2646-2659. [CrossRef]

88. Lu, J.; Li, B.; Xiong, X.; Cheng, N. RNA sequencing reveals the long noncoding RNA and mRNA profiles and identifies long noncoding RNA TSPAN12 as a potential microvascular invasion-related biomarker in hepatocellular carcinoma. Biomed. Pharmacother. 2020, 126, 110111. [CrossRef]

89. Yu, S.; Li, N.; Wang, J.; Fu, Y.; Huang, Y.; Yi, P.; Chen, R.; Tang, D.; Hu, X.; Fan, X. Correlation of Long Noncoding RNA SEMA6AAS1 Expression with Clinical Outcome in HBV-Related Hepatocellular Carcinoma. Clin. Ther. 2020, 42, 439-447. [CrossRef]

90. Shi, X.M.; Teng, F. Up-regulation of long non-coding RNA Sox2ot promotes hepatocellular carcinoma cell metastasis and correlates with poor prognosis. Int. J. Clin. Exp. Pathol. 2015, 8, 4008-4014.

91. Kamel, M.M.; Matboli, M.; Sallam, M.; Montasser, I.F.; Saad, A.S.; El-Tawdi, A.H.F. Investigation of long noncoding RNAs expression profile as potential serum biomarkers in patients with hepatocellular carcinoma. Transl. Res. 2016, 168, 134-145. [CrossRef]

92. Peng, W.; Fan, H. Long non-coding RNA PANDAR correlates with poor prognosis and promotes tumorigenesis in hepatocellular carcinoma. Biomed. Pharmacother. 2015, 72, 113-118. [CrossRef]

93. Quagliata, L.; Matter, M.S.; Piscuoglio, S.; Arabi, L.; Ruiz, C.; Procino, A.; Kovac, M.; Moretti, F.; Makowska, Z.; Boldanova, T.; et al. Long noncoding RNA HOTTIP/HOXA13 expression is associated with disease progression and predicts outcome in hepatocellular carcinoma patients. Hepatology 2014, 59, 911-923. [CrossRef]

94. Sun, L.; Su, Y.; Liu, X.; Xu, M.; Chen, X.; Zhu, Y.; Guo, Z.; Bai, T.; Dong, L.; Wei, C.; et al. Serum and exosome long non coding RNAs as potential biomarkers for hepatocellular carcinoma. J. Cancer 2018, 9, 2631-2639. [CrossRef]

95. Lim, L.J.; Ling, L.H.; Neo, Y.P.; Chung, A.Y.F.; Goh, B.K.P.; Chow, P.K.H.; Chan, C.Y.; Cheow, P.C.; Lee, S.Y.; Lim, T.K.H.; et al. Highly deregulated lncRNA LOC is associated with overall worse prognosis in Hepatocellular Carcinoma patients. J. Cancer 2021, 12, 3098-3113. [CrossRef]

96. Li, Y.; Li, G.; Chen, X.; Huang, H.; Liao, L.; Yuan, T.; Deng, S. A Novel lncRNA NONHSAT053785 Acts as an Independent Risk Factor for Intrahepatic Metastasis of Hepatocellular Carcinoma. Onco Targets 2020, 13, 5455-5466. [CrossRef] [PubMed]

97. Guo, X.; Lv, X.; Lv, X.; Ma, Y.; Chen, L.; Chen, Y. Circulating miR-21 serves as a serum biomarker for hepatocellular carcinoma and correlated with distant metastasis. Oncotarget 2017, 8, 44050-44058. [CrossRef]

98. Zhao, X.F.; Li, N.; Lin, D.D.; Sun, L.B. Circulating MicroRNA-122 for the Diagnosis of Hepatocellular Carcinoma: A Meta-Analysis. Biomed. Res. Int. 2020, 2020, 5353695. [CrossRef] [PubMed]

99. Bharali, D.; Banerjee, B.D.; Bharadwaj, M.; Husain, S.A.; Kar, P. Expression Analysis of MicroRNA-21 and MicroRNA-122 in Hepatocellular Carcinoma. J. Clin. Exp. Hepatol. 2019, 9, 294-301. [CrossRef] [PubMed]

100. Mohamed, A.A.; Omar, A.A.A.; El-Awady, R.R.; Hassan, S.M.A.; Eitah, W.M.S.; Ahmed, R.; Khater, A.; Tantawi, O.M.S.; Mohamed, A.A. MiR-155 and MiR-665 Role as Potential Non-invasive Biomarkers for Hepatocellular Carcinoma in Egyptian Patients with Chronic Hepatitis C Virus Infection. J. Transl. Int. Med. 2020, 8, 32-40. [CrossRef]

101. Han, J.; Li, J.; Qian, Y.; Liu, W.; Liang, J.; Huang, Z.; Wang, S.; Zhao, C. Identification of plasma miR-148a as a noninvasive biomarker for hepatocellular carcinoma. Clin. Res. Hepatol. Gastroenterol. 2019, 43, 585-593. [CrossRef] [PubMed]

102. Cho, H.J.; Eun, J.W.; Baek, G.O.; Seo, C.W.; Ahn, H.R.; Kim, S.S.; Cho, S.W.; Cheong, J.Y. Serum Exosomal MicroRNA, miR-10b-5p, as a Potential Diagnostic Biomarker for Early-Stage Hepatocellular Carcinoma. J. Clin. Med. 2020, 9, 281. [CrossRef] [PubMed] 
103. Ghosh, A.; Ghosh, A.; Datta, S.; Dasgupta, D.; Das, S.; Ray, S.; Gupta, S.; Datta, S.; Chowdhury, A.; Chatterjee, R.; et al. Hepatic miR-126 is a potential plasma biomarker for detection of hepatitis B virus infected hepatocellular carcinoma. Int. J. Cancer 2016, 138, 2732-2744. [CrossRef] [PubMed]

104. Yang, C.; Du, P.; Lu, W. MiR-424 Acts as a Novel Biomarker in the Diagnosis of Patients with Hepatocellular Carcinoma. Cancer Biother. Radiopharm. 2021, 34287021. [CrossRef]

105. Peng, C.; Ye, Y.; Wang, Z.; Guan, L.; Bao, S.; Li, B.; Li, W. Circulating microRNAs for the diagnosis of hepatocellular carcinoma. Dig. Liver Dis. 2019, 51, 621-631. [CrossRef]

106. Lurje, I.; Czigany, Z.; Bednarsch, J.; Roderburg, C.; Isfort, P.; Neumann, U.P.; Lurje, G. Treatment Strategies for Hepatocellular Carcinoma -a Multidisciplinary Approach. Int. J. Mol. Sci. 2019, 20, 1465. [CrossRef]

107. Song, W.; Zheng, C.; Liu, M.; Xu, Y.; Qian, Y.; Zhang, Z.; Su, H.; Li, X.; Wu, H.; Gong, P.; et al. TRERNA1 upregulation mediated by HBx promotes sorafenib resistance and cell proliferation in HCC via targeting NRAS by sponging miR-22-3p. Mol. Ther. 2021. [CrossRef]

108. Zhou, Y.; Huang, Y.; Dai, T.; Hua, Z.; Xu, J.; Lin, Y.; Han, L.; Yue, X.; Ho, L.; Lu, J.; et al. LncRNA TTN-AS1 intensifies sorafenib resistance in hepatocellular carcinoma by sponging miR-16-5p and upregulation of cyclin E1. Biomed. Pharmacother. 2021, 133, 111030. [CrossRef]

109. Zhang, J.; Zhao, X.; Ma, X.; Yuan, Z.; Hu, M. KCNQ1OT1 contributes to sorafenib resistance and programmed death-ligand-1mediated immune escape via sponging miR-506 in hepatocellular carcinoma cells. Int. J. Mol. Med. 2020, 46, 1794-1804. [CrossRef]

110. Chen, B.W.; Zhou, Y.; Wei, T.; Wen, L.; Zhang, Y.B.; Shen, S.C.; Zhang, J.; Ma, T.; Chen, W.; Ni, L.; et al. IncRNA-POIR promotes epithelial-mesenchymal transition and suppresses sorafenib sensitivity simultaneously in hepatocellular carcinoma by sponging miR-182-5p. J. Cell Biochem. 2021, 122, 130-142. [CrossRef]

111. Xu, Y.; Liu, Y.; Li, Z.; Li, H.; Li, X.; Yan, L.; Mao, J.; Shen, J.; Chen, W.; Xue, F. Long non-coding RNA H19 is involved in sorafenib resistance in hepatocellular carcinoma by upregulating miR-675. Oncol. Rep. 2020, 44, 165-173. [CrossRef]

112. Tang, X.; Zhang, W.; Ye, Y.; Li, H.; Cheng, L.; Zhang, M.; Zheng, S.; Yu, J. LncRNA HOTAIR Contributes to Sorafenib Resistance through Suppressing miR-217 in Hepatic Carcinoma. Biomed. Res. Int. 2020, 2020, 9515071. [CrossRef]

113. Jing, Z.; Ye, X.; Ma, X.; Hu, X.; Yang, W.; Shi, J.; Chen, G.; Gong, L. SNGH16 regulates cell autophagy to promote Sorafenib Resistance through suppressing miR-23b-3p via sponging EGR1 in hepatocellular carcinoma. Cancer Med. 2020, 9, 4324-4338. [CrossRef]

114. Fan, L.; Huang, X.; Chen, J.; Zhang, K.; Gu, Y.H.; Sun, J.; Cui, S.Y. Long Noncoding RNA MALAT1 Contributes to Sorafenib Resistance by Targeting miR-140-5p/Aurora-A Signaling in Hepatocellular Carcinoma. Mol. Cancer Ther. 2020, 19, 1197-1209. [CrossRef]

115. Shi, Y.; Yang, X.; Xue, X.; Sun, D.; Cai, P.; Song, Q.; Zhang, B.; Qin, L. HANR Enhances Autophagy-Associated Sorafenib Resistance Through miR-29b/ATG9A Axis in Hepatocellular Carcinoma. Onco Targets 2020, 13, 2127-2137. [CrossRef]

116. Li, X.; Zhou, Y.; Yang, L.; Ma, Y.; Peng, X.; Yang, S.; Li, H.; Liu, J. LncRNA NEAT1 promotes autophagy via regulating miR-204/ATG3 and enhanced cell resistance to sorafenib in hepatocellular carcinoma. J. Cell. Physiol. 2020, 235, 3402-3413. [CrossRef] [PubMed]

117. Sui, C.; Dong, Z.; Yang, C.; Zhang, M.; Dai, B.; Geng, L.; Lu, J.; Yang, J.; Xu, M. LncRNA FOXD2-AS1 as a competitive endogenous RNA against miR-150-5p reverses resistance to sorafenib in hepatocellular carcinoma. J. Cell Mol. Med. 2019, 23, 6024-6033. [CrossRef] [PubMed]

118. Yu, T.; Yu, J.; Lu, L.; Zhang, Y.; Zhou, Y.; Zhou, Y.; Huang, F.; Sun, L.; Guo, Z.; Hou, G.; et al. MT1JP-mediated miR-243p/BCL2L2 axis promotes Lenvatinib resistance in hepatocellular carcinoma cells by inhibiting apoptosis. Cell Oncol. 2021, 44, 821-834. [CrossRef] [PubMed]

119. Hu, Y.; Zhang, X.; Zai, H.Y.; Jiang, W.; Xiao, L.; Zhu, Q. IncRNA DUXAP8 Facilitates Multiple Malignant Phenotypes and Resistance to PARP Inhibitor in HCC via Upregulating FOXM1. Mol. Ther. Oncolytics 2020, 19, 308-322. [CrossRef] [PubMed]

120. Huang, G.; Li, L.; Liang, C.; Yu, F.; Teng, C.; Pang, Y.; Wei, T.; Song, J.; Wang, H.; Liao, X.; et al. Upregulated UCA1 contributes to oxaliplatin resistance of hepatocellular carcinoma through inhibition of miR-138-5p and activation of AKT/mTOR signaling pathway. Pharmacol. Res. Perspect. 2021, 9, e00720. [CrossRef]

121. Huang, H.; Chen, J.; Ding, C.M.; Jin, X.; Jia, Z.M.; Peng, J. LncRNA NR2F1-AS1 regulates hepatocellular carcinoma oxaliplatin resistance by targeting ABCC1 via miR-363. J. Cell Mol. Med. 2018, 22, 3238-3245. [CrossRef]

122. Cao, Y.; Zhang, F.; Wang, H.; Bi, C.; Cui, J.; Liu, F.; Pan, H. LncRNA MALAT1 mediates doxorubicin resistance of hepatocellular carcinoma by regulating miR-3129-5p/Nova1 axis. Mol. Cell Biochem. 2021, 476, 279-292. [CrossRef]

123. Gao, J.; Dai, C.; Yu, X.; Yin, X.B.; Zhou, F. Long noncoding RNA LEF1-AS1 acts as a microRNA-10a-5p regulator to enhance MSI1 expression and promote chemoresistance in hepatocellular carcinoma cells through activating AKT signaling pathway. J. Cell Biochem. 2021, 122, 86-99. [CrossRef]

124. Zhao, P.; Cui, X.; Zhao, L.; Liu, L.; Wang, D. Overexpression of Growth-Arrest-Specific Transcript 5 Improved Cisplatin Sensitivity in Hepatocellular Carcinoma Through Sponging miR-222. DNA Cell Biol. 2020, 39, 724-732. [CrossRef] [PubMed]

125. Chen, Y.; Zhao, H.; Li, H.; Feng, X.; Tang, H.; Qiu, C.; Zhang, J.; Fu, B. LINC01234/MicroRNA-31-5p/MAGEA3 Axis Mediates the Proliferation and Chemoresistance of Hepatocellular Carcinoma Cells. Mol. Ther. Nucleic. Acids 2020, 19, 168-178. [CrossRef]

126. Nishida, N. Role of Oncogenic Pathways on the Cancer Immunosuppressive Microenvironment and Its Clinical Implications in Hepatocellular Carcinoma. Cancers 2021, 13, 3666. [CrossRef] 
127. Xia, Y.; Brown, Z.J.; Huang, H.; Tsung, A. Metabolic reprogramming of immune cells: Shaping the tumor microenvironment in hepatocellular carcinoma. Cancer Med. 2021, 10, 6374-6383. [CrossRef] [PubMed]

128. Gramantieri, L.; Giovannini, C.; Piscaglia, F.; Fornari, F. MicroRNAs as Modulators of Tumor Metabolism, Microenvironment, and Immune Response in Hepatocellular Carcinoma. J. Hepatocell. Carcinoma 2021, 8, 369-385. [CrossRef] [PubMed]

129. Bao, M.H.; Wong, C.C. Hypoxia, Metabolic Reprogramming, and Drug Resistance in Liver Cancer. Cells 2021, 10, 1715. [CrossRef] [PubMed]

130. Song, Y.; Jin, X.; Liu, Y.; Wang, S.; Bian, F.; Zhao, Q.; Shi, H.; Gao, Z. Long noncoding RNA ZFPM2-AS1 promotes the proliferation, migration, and invasion of hepatocellular carcinoma cells by regulating the miR-576-3p/HIF-1 $\alpha$ axis. Anticancer Drugs 2021, 32, 812-821. [CrossRef]

131. Yan, C.; Wei, S.; Han, D.; Wu, L.; Tan, L.; Wang, H.; Dong, Y.; Hua, J.; Yang, W. LncRNA HULC shRNA disinhibits miR-377-5p to suppress the growth and invasion of hepatocellular carcinoma in vitro and hepatocarcinogenesis in vivo. Ann. Transl. Med. 2020, 8, 1294. [CrossRef] [PubMed]

132. Wang, L.; Sun, L.; Liu, R.; Mo, H.; Niu, Y.; Chen, T.; Wang, Y.; Han, S.; Tu, K.; Liu, Q. Long non-coding RNA MAPKAPK5AS1/PLAGL2/HIF-1 $\alpha$ signaling loop promotes hepatocellular carcinoma progression. J. Exp. Clin. Cancer Res. 2021, 40, 72. [CrossRef]

133. Zhang, Q.; Cheng, Q.; Xia, M.; Huang, X.; He, X.; Liao, J. Hypoxia-Induced lncRNA-NEAT1 Sustains the Growth of Hepatocellular Carcinoma via Regulation of miR-199a-3p/UCK2. Front. Oncol. 2020, 10, 998. [CrossRef] [PubMed]

134. Yang, X.; Yao, B.; Niu, Y.; Chen, T.; Mo, H.; Wang, L.; Guo, C.; Yao, D. Hypoxia-induced lncRNA EIF3J-AS1 accelerates hepatocellular carcinoma progression via targeting miR-122-5p/CTNND2 axis. Biochem. Biophys. Res. Commun. 2019, 518, 239-245. [CrossRef]

135. Zhou, Y.; Huang, Y.; Hu, K.; Zhang, Z.; Yang, J.; Wang, Z. HIF1A activates the transcription of lncRNA RAET1K to modulate hypoxia-induced glycolysis in hepatocellular carcinoma cells via miR-100-5p. Cell Death Dis. 2020, 11, 176. [CrossRef]

136. Hu, M.; Fu, Q.; Jing, C.; Zhang, X.; Qin, T.; Pan, Y. LncRNA HOTAIR knockdown inhibits glycolysis by regulating miR-130a3p/HIF1A in hepatocellular carcinoma under hypoxia. Biomed. Pharmacother. 2020, 125, 109703. [CrossRef]

137. He, H.; Chen, T.; Mo, H.; Chen, S.; Liu, Q.; Guo, C. Hypoxia-inducible long noncoding RNA NPSR1-AS1 promotes the proliferation and glycolysis of hepatocellular carcinoma cells by regulating the MAPK/ERK pathway. Biochem. Biophys. Res. Commun. 2020 533, 886-892. [CrossRef]

138. Wang, T.H.; Yu, C.C.; Lin, Y.S.; Chen, T.C.; Yeh, C.T.; Liang, K.H.; Shieh, T.M.; Chen, C.Y.; Hsueh, C. Long noncoding RNA CPS1IT1 suppresses the metastasis of hepatocellular carcinoma by regulating HIF-1 $\alpha$ activity and inhibiting epithelial-mesenchymal transition. Oncotarget 2016, 7, 43588-43603. [CrossRef]

139. Yu, Z.; Zhao, H.; Feng, X.; Li, H.; Qiu, C.; Yi, X.; Tang, H.; Zhang, J. Long Non-coding RNA FENDRR Acts as a miR-423-5p Sponge to Suppress the Treg-Mediated Immune Escape of Hepatocellular Carcinoma Cells. Mol. Ther Nucleic. Acids 2019, 17, 516-529. [CrossRef]

140. Jiang, R.; Tang, J.; Chen, Y.; Deng, L.; Ji, J.; Xie, Y.; Wang, K.; Jia, W.; Chu, W.M.; Sun, B. The long noncoding RNA lnc-EGFR stimulates T-regulatory cells differentiation thus promoting hepatocellular carcinoma immune evasion. Nat. Commun. 2017, 8, 15129. [CrossRef] [PubMed]

141. Yan, K.; Fu, Y.; Zhu, N.; Wang, Z.; Hong, J.L.; Li, Y.; Li, W.J.; Zhang, H.B.; Song, J.H. Repression of lncRNA NEAT1 enhances the antitumor activity of CD8+T cells against hepatocellular carcinoma via regulating miR-155/Tim-3. Int. J. Biochem. Cell Biol. 2019, 110, 1-8. [CrossRef] [PubMed]

142. Ji, J.; Yin, Y.; Ju, H.; Xu, X.; Liu, W.; Fu, Q.; Hu, J.; Zhang, X.; Sun, B. Long non-coding RNA Lnc-Tim3 exacerbates CD8 T cell exhaustion via binding to Tim-3 and inducing nuclear translocation of Bat3 in HCC. Cell Death Dis. 2018, 9, 478. [CrossRef]

143. Chen, J.; Huang, Z.B.; Liao, C.J.; Hu, X.W.; Li, S.L.; Qi, M.; Fan, X.G.; Huang, Y. LncRNA TP73-AS1/miR-539/MMP8 axis modulates M2 macrophage polarization in hepatocellular carcinoma via TGF- $\beta 1$ signaling. Cell Signal. 2020, 75, 109738. [CrossRef] [PubMed]

144. Wang, L.P.; Lin, J.; Ma, X.Q.; Xu, D.Y.; Shi, C.F.; Wang, W.; Jiang, X.J. Exosomal DLX6-AS1 from hepatocellular carcinoma cells induces M2 macrophage polarization to promote migration and invasion in hepatocellular carcinoma through microRNA-15a5p/CXCL17 axis. J. Exp. Clin. Cancer Res. 2021, 40, 177. [CrossRef] [PubMed]

145. Li, X.; Lei, Y.; Wu, M.; Li, N. Regulation of Macrophage Activation and Polarization by HCC-Derived Exosomal lncRNA TUC339. Int. J. Mol. Sci. 2018, 19, 2958. [CrossRef]

146. Li, Z.; Wu, T.; Zheng, B.; Chen, L. Individualized precision treatment: Targeting TAM in HCC. Cancer Lett. 2019, 458, 86-91. [CrossRef]

147. Chung, J.Y.; Chan, M.K.; Li, J.S.; Chan, A.S.; Tang, P.C.; Leung, K.T.; To, K.F.; Lan, H.Y.; Tang, P.M. TGF- $\beta$ Signaling: From Tissue Fibrosis to Tumor Microenvironment. Int. J. Mol. Sci. 2021, 22, 7575. [CrossRef]

148. Wang, Y.; Yang, L.; Dong, X.; Yang, X.; Zhang, X.; Liu, Z.; Zhao, X.; Wen, T. Overexpression of NNT-AS1 Activates TGF- $\beta$ Signaling to Decrease Tumor CD4 Lymphocyte Infiltration in Hepatocellular Carcinoma. Biomed. Res. Int. 2020, 2020, 8216541. [CrossRef]

149. Lou, J.; Yan, W.; Li, Q.Y.; Zhu, A.K.; Tan, B.Q.; Dong, R.; Zou, X.Z.; Liu, T. LncRNA MEG8 plays an oncogenic role in hepatocellular carcinoma progression through miR-367-3p/14-3-3乙/TGFßR1 axis. Neoplasma 2021, 68, 273-282. [CrossRef] 
150. Lin, Y.; Jian, Z.; Jin, H.; Wei, X.; Zou, X.; Guan, R.; Huang, J. Long non-coding RNA DLGAP1-AS1 facilitates tumorigenesis and epithelial-mesenchymal transition in hepatocellular carcinoma via the feedback loop of miR-26a/b-5p/IL-6/JAK2/STAT3 and Wnt/ $\beta$-catenin pathway. Cell Death Dis. 2020, 11, 34. [CrossRef]

151. Zhang, J.; Li, Z.; Liu, L.; Wang, Q.; Li, S.; Chen, D.; Hu, Z.; Yu, T.; Ding, J.; Li, J.; et al. Long noncoding RNA TSLNC8 is a tumor suppressor that inactivates the interleukin-6/STAT3 signaling pathway. Hepatology 2018, 67, 171-187. [CrossRef]

152. Hou, Z.H.; Xu, X.W.; Fu, X.Y.; Zhou, L.D.; Liu, S.P.; Tan, D.M. Long non-coding RNA MALAT1 promotes angiogenesis and immunosuppressive properties of HCC cells by sponging miR-140. Am. J. Physiol. Cell Physiol. 2020, 318, C649-C663. [CrossRef] [PubMed]

153. Reda, E.; Sayed, S.; Cristante, J.; Guyon, L.; Denis, J.; Chabre, O.; Cherradi, N. MicroRNA Therapeutics in Cancer: Current Advances and Challenges. Cancers 2021, 13, 2680. [CrossRef] [PubMed]

154. Shi, T.; Morishita, A.; Kobara, H.; Masaki, T. The Role of microRNAs in Cholangiocarcinoma. Int. J. Mol. Sci. 2021, 22, 7627. [CrossRef] [PubMed]

155. Winkle, M.; El-Daly, S.M.; Fabbri, M.; Calin, G.A. Noncoding RNA therapeutics-Challenges and potential solutions. Nat. Rev. Drug Discov. 2021, 20, 629-651. [CrossRef]

156. Liu, R.; Wang, X.; Shen, Y.; He, A. Long non-coding RNA-based glycolysis-targeted cancer therapy: Feasibility, progression and limitations. Mol. Biol. Rep. 2021, 48, 2713-2727. [CrossRef]

157. Hong, D.S.; Kang, Y.K.; Borad, M.; Sachdev, J.; Ejadi, S.; Lim, H.Y.; Brenner, A.J.; Park, K.; Lee, J.L.; Kim, T.Y.; et al. Phase 1 study of MRX34, a liposomal miR-34a mimic, in patients with advanced solid tumours. Br. J. Cancer 2020, 122, 1630-1637. [CrossRef]

158. Van Zandwijk, N.; Pavlakis, N.; Kao, S.C.; Linton, A.; Boyer, M.J.; Clarke, S.; Huynh, Y.; Chrzanowska, A.; Fulham, M.J.; Bailey, D.L.; et al. Safety and activity of microRNA-loaded minicells in patients with recurrent malignant pleural mesothelioma: A first-in-man, phase 1, open-label, dose-escalation study. Lancet Oncol. 2017, 18, 1386-1396. [CrossRef] 